\title{
Fate and Effects in Soil of Cry Proteins from Bacillus thuringiensis: Influence of Physicochemical and Biological Characteristics of Soil
}

\author{
Deepak Saxena*, ${ }^{1}$, Smruti Pushalkar ${ }^{1}$ and Guenther Stotzky ${ }^{2}$ \\ ${ }^{1}$ College of Dentistry, ${ }^{2}$ Faculty of Arts and Science, New York University, New York, NY 10010, USA
}

\begin{abstract}
Bacillus thuringiensis (Bt) is a useful alternative or supplement to synthetic chemical pesticides in agriculture, forest management, and control of mosquitoes and some other biting insects. When modified Bt cry genes are inserted into a plant species (e.g., corn, cotton, potato, canola, rice), the plant expresses active larvicidal proteins in its tissues. The toxins continue to be synthesized during growth of the plants, making the plant toxic to various insect pests throughout their life or as biomass incorporated into soil. If production exceeds consumption, inactivation, and degradation, the toxins could accumulate to concentrations that may enhance the control of target pests or constitute a hazard to nontarget organisms, such as the soil microbiota, beneficial insects (e.g., pollinators, predators and parasites of insect pests), and other animal classes. The accumulation and persistence of the toxins could also result in the selection and enrichment of toxin-resistant target insects. Persistence is enhanced when the toxins are bound on surface-active particles in the environment (e.g., clays and humic substances) and, thereby, rendered more resistant to biodegradation while retaining toxic activity. Moreover, major problem we face today is of "Molecular pharming" that utilizes transgenic plants and animals for production of pharmaceuticals and chemicals for their use in human beings and industries respectively. Their release to the environment, especially to soil and potentially to waters of the pharmaceutical and industrial products of transgenic plant and animal "pharms" could pose a hazard to the environment. In contrast to the products of most transgenic plants currently available commercially (e.g., the insecticidal proteins from subspecies of $B t$ ) that primarily target insects and other pests. These "pharms" are being genetically engineered to express products for use primarily in human beings. Consequently, these products constitute a class of compounds that is seldom found in natural habitats and that primarily target "higher level" eukaryotes. Hence, they are xenobiotics with respect to the environment, and their persistence in and effects on the environment have not been adequately studied and sober risk assessments on a case-bycase basis must be made before major releases of such transgenic organisms.
\end{abstract}

Keywords: Bacillus thuringiensis, $B t$ toxins, biopesticide, adsorption, binding, microbial degradation, transgenic crops.

\section{BACILLUS THURINGIENSIS (Bt) AS A BIOLOGICAL PESTICIDE/BIOPESTICIDE}

Bacillus thuringiensis $(B t)$ is a gram-positive, aerobic, spore-forming, rod-shaped bacterium that produces a parasporal, crystalline proteinaceous, inclusion during sporulation in the stationary phase of growth. This inclusion may contain more than one type of insecticidal crystal protein (ICP). These proteins, which are released with the endospore upon lysis of the sporangium, exhibit, after appropriate processing, specific toxicities to insects, many of which are economically important crop pests. The primary site of action of the insecticidal toxins of various subspecies of $B$. thuringiensis is the brush border membranes of the midgut epithelium of susceptible larvae of Lepidoptera, Coleoptera, and Diptera [1,2]. The nontoxic, parasporal, crystalline inclusions (protoxins) are solubilized after ingestion by larvae in the alkaline midgut $(\mathrm{pH}>10)$ and proteolytically activated into toxins by specific proteases [3]. The active toxins interact with receptors on midgut epithelial cells, where the toxins form pores and destroy cells

*Address correspondence to this author at the Department of Basic Science and Craniofacial Biology, New York University College of Dentistry, 345 E. $24^{\text {th }}$ Street, Room 921B, New York, NY 10010, USA;

Tel.: +1 212998 9256; Fax: +1 212995 4087; E-mail: ds100@nyu.edu by osmotic lysis [4, 5]. Larvae of nontarget insects also contain receptors but apparently in lower numbers $[3,6]$, although, in some cases, also in high numbers [5, 7].

The ICPs have been classified into five families (I-V), four classes (A-D), and three subclasses (a-c) on the basis of their structure, encoding genes, host range, and on the flagellar $\mathrm{H}$-antigens of the bacteria that produce them [3, 8]. Numerous distinct crystal protein (cry) genes code for insecticidal proteins (Cry proteins): e.g., CryI and CryIIB proteins are specifically toxic to Lepidoptera; CryIIA proteins to Lepidoptera and Diptera; CryIII proteins to Coleoptera; and four CryIV proteins to Diptera. In addition, two genes $(c y t A, c y t B)$ that code for cytolytic proteins (CytA, $\mathrm{CytB})$ are present with the CryIV proteins. However, this nomenclature has been revised [8] but will be, in part, retained here, as many of the published studies discussed in this article were done while the old nomenclature was used. Various strains of $B t$, each with different Cry proteins, and more than 60 Cry proteins have been identified. Most $B t$ maize hybrids express the Cry1 $\mathrm{Ab}$ protein, and a few express the Cry1Ac or the Cry9C protein, all of which are targeted against the European corn borer (Ostrinia nubilalis Hübner) (Lepidoptera), a major pest of maize in North America and Europe. Some recent maize hybrids express the Cry3Bb1 protein, which is targeted against the corn rootworm 
complex (Diabrotica spp.) (Coleoptera), also a major pest of maize, especially in North America. Cotton expressing the Cry1Ac protein is targeted against the cotton bollworm (Helicoverpa zea Boddie) (Lepidoptera), which is a major pest of cotton; potato expressing the Cry $3 \mathrm{~A}$ or Cry $3 \mathrm{C}$ is targeted against the Colorado potato beetle (Leptinotarsa decemlineata Say) (Coleoptera), which is a major pest of potato; and Cry4 proteins are targeted against some Diptera, such as certain flies (e.g., Lycoriella castanescens Lengersdorf) and mosquitoes (e.g., Culex pipiens Linnaeus). Some Cry proteins exhibit activity against other orders of insects (e.g., Homoptera, Hymenoptera, Orthoptera, Mallophaga), as well as against nematodes, mites, collembolans, and protozoa [3, 9-12]. Some strains of $B t$ are also specifically active against human cancer cells [13-21].

B. thuringiensis is a useful alternative or supplement to synthetic chemical pesticides in agriculture, forest management, and control of mosquitoes and some other biting insects. Bioinsecticides, based on a mixture of cells, spores, and parasporal crystals of subspecies of $B$. thuringiensis, have been used since the early 1960's for the control of various species of insects $[22,23]$ and against nematodes, mites, and protozoa $[24,25]$. B. thuringiensis encoding larvicidal Cry proteins is the active ingredient of commercial $B t$ insecticidal sprays used for many years (e.g., Dipel, Xentari, Javlin, Foray, M-One, VIP). The bacteria are also the major source of genes for the expression of pest resistance in transgenic plants. Truncated forms of the genes that code for these toxins have been genetically engineered into plants that express the active toxins rather than the inactive protoxins. When modified cry genes are inserted into a plant species (e.g., corn, cotton, potato, canola, rice), the plant expresses active larvicidal proteins in its tissues, making the plant toxic to various insect pests [26]. After commercially usable portion of transgenic plants have been harvested, the remainder of the plant biomass containing the toxins is usually incorporated into soil where the biomass is degraded and the toxins released. The toxins are also released in pollen [27, 28] and in root exudates [29-31]. As a high gut $\mathrm{pH}$ and specific proteases are not essential to activate the toxins released by transgenic plants, beneficial nontarget insects, as well as organisms at higher and lower trophic levels, could be harmed [32-35]. Hence, the largescale release of genetically-modified $B t$ crops remains a concern due to their presumed potential ecological and environmental risks.

\section{PERSISTENCE OF TOXINS AND CELLS OF $B$. THURINGIENSIS IN SOIL:}

Essentially no unexpected toxicities from $B t$ sprays have been recorded [29], probably because $B t$ does not survive or grow well in soil [36-42], and its spores are rapidly inactivated by UV radiation [43, 44]. Consequently, there is probably little production of toxins in soil [45], and the persistence of introduced toxins is a function primarily of the: (1) amount added; (2) rate of consumption and inactivation by insect larvae; (3) rate of degradation by microorganisms; and (4) rate of abiotic inactivation. However, when the genes that code for these toxins are genetically engineered into plants, the toxins continue to be synthesized during growth of the plants. If production exceeds consumption, inactivation, and degradation, the toxins could accumulate to concentrations that may enhance the control of target pests or constitute a hazard to nontarget organisms, such as the soil microbiota, beneficial insects (e.g., pollinators, predators and parasites of insect pests) [27, $28,32-35,46-49]$, and other animal classes. The accumulation and persistence of the toxins could also result in the selection and enrichment of toxin-resistant target insects [23, 50-55]. Persistence is enhanced when the toxins are bound on surface-active particles in the environment (e.g., clays and humic substances) and, thereby, rendered more resistant to biodegradation while retaining toxic activity [12, 29, 56, 57].

In vitro studies were conducted with purified toxins and different soils, relatively well-defined clays, and humic acids to determine whether toxins released in situ from transgenic plants or commercial $B t$ spray preparations are adsorbed and bound on such surface-active particles and whether this affects their persistence, retention of insecticidal activity, and accessibility for microbial degradation in soil.

\subsection{Adsorption and Binding of $B t$ Toxins on Different Substrates and their Subsequent Insecticidal Activity}

Montmorillonite (M), a swelling 2:1 Si:Al clay, and kaolinite $(\mathrm{K})$, a nonswelling 1:1 Si:Al clay, are the predominant clay minerals in many soils, and these clays differ in structure and numerous physicochemical characteristics (e.g., cation-exchange capacity, specific surface area) and in their effects on biological activity in soil [58]. The toxins and protoxins were purified from pure cultures and commercial sources of subspecies of $B t$, and the clay minerals, various size fractions of soil, and humic acids were prepared as described in the references in Stotzky [58].

\subsubsection{Adsorption and Binding of Purified Bt Toxins on Clay Minerals and the Clay-, Silt-, and Sand-Size Fractions of Soil}

The adsorption and binding of purified toxins produced by $B$. thuringiensis subsp. kurstaki (Btk; $66 \mathrm{kDa}$; active against Lepidoptera), subsp. morrisoni (strain tenebrionis) $(B t t ; 68 \mathrm{kDa})$ and subsp. kumamotoensis $(B t k u ; 74 \mathrm{kDa})$ (both active against Coleoptera), and subsp. israelensis (Bti: 28 to $130 \mathrm{kDa}$; active against some Diptera) on $\mathrm{M}$ and $\mathrm{K}$ and on the clay-, silt-, and sand-size fractions of soil [10, 29, 5967] was studied.

The toxins from Btk and Btt were rapidly adsorbed (at equilibrium) in $<30 \mathrm{~min}$, the shortest time studied, and tightly bound (after "ultimate" washing) on M and K, either containing a mixed cation complement, homoionic to different cations ("clean" clays), or coated with two types of polymeric oxyhydroxides of Fe(III) ("dirty" clays), as well as on the clay-size fraction separated from soil $[61,64$, 66]. Only about 10 and $30 \%$ of the toxin from Btk and $B t t$, respectively, adsorbed at equilibrium was desorbed by one or two washes with water, and additional washing desorbed no more toxins, indicating that the toxins were tightly bound on the clays [61]. Consequently, toxins released from transgenic plant or microbial biomass containing cry genes from various subspecies of $B$. thuringiensis, calculated for transgenic plants to range from 5 to $100 \mathrm{ng}$ of toxins/g of soil [64], would be free and susceptible to microbial degradation in soil for only a short time. Interaction of the toxins with the 
clays did not significantly alter the structure of the toxins, as indicated by sodium dodecyl sulfate-polyacrylamide gel electrophoresis (SDS-PAGE) and enzyme-linked immunosorbent assay (ELISA) of the equilibrium supernatants and desorption washes and by Fourier transform infrared (FTIR) analyses and insect bioassays of the bound toxins. The toxins only partially intercalated $\mathrm{M}$, as determined by X-ray diffraction analyses, and there was no intercalation of $\mathrm{K}$, a nonexpanding clay mineral.

Toxins from Btk and Btt, either free or adsorbed or bound on $\mathrm{M}$ or $\mathrm{K}$ or on the clay-size fraction separated from soil, were detected by a dot-blot ELISA, with a lower limit of detection of ca. $3 \mathrm{ng}$, but not on the silt- and sand-size fractions on which the toxins do not appear to adsorb or bind [63]. The adsorbed and bound toxins retained their insecticidal activity. The toxins added to sterile and nonsterile soil amended with $\mathrm{M}$ or $\mathrm{K}$ or not amended with clay were detected on the clay-size fraction of the soil after various periods of incubation, whereas no toxins were detected on the silt- and sand-size fractions. The toxins were still detectable on the clay-size fraction of nonsterile soil after 40 days, in agreement with the results of other studies in this laboratory that binding of these toxins on clay minerals renders them resistant to utilization by microorganisms [68].

The toxin from Btk or Btt bound on M, K, or the clay-size fraction was larvicidal to the tobacco hornworm (Manduca sexta Linnaeus) or the Colorado potato beetle (Leptinotarsa decemlineata Say), respectively [64]. The 50\% lethal concentration $\left(\mathrm{LC}_{50}\right)$ of free $B t k$ toxin was higher than that of both bound and adsorbed complexes with clays, indicating that adsorption and binding of these toxins on clays increased their toxicity in diet bioassays. The $\mathrm{LC}_{50}$ of the $\mathrm{Btt}$ toxin, either free or adsorbed on $\mathrm{M}$, was comparable, whereas it was higher with the bound toxin. The toxin bound on $\mathrm{K}$ had a lower $\mathrm{LC}_{50}$ than adsorbed toxin. The results obtained with the clay-size fraction separated from unamended soil or from soil amended with $\mathrm{M}$ or $\mathrm{K}$ were similar to those obtained with the respective pure clay minerals. Therefore, insecticidal activity of these toxins is apparently retained and, sometimes, enhanced by adsorption and binding on clays.

A rapid and sensitive method using flow cytometry was developed to detect the toxins bound on particles in soil that do not require their extraction and purification and which enabled more rapid processing of numerous samples [65]. The Btk and Btt toxins were bound on clay- and silt-sized particles separated from a soil that was unamended (the soil naturally contains predominantly $\mathrm{K}$ ) or amended to $6 \%(\mathrm{v} / \mathrm{v})$ with $\mathrm{M}$ or $\mathrm{K}$, the latter as an internal control. The nonspecific binding of antibody ( $\mathrm{Ab}$ ) was blocked by suspending the particle-toxin mixtures in $0.1 \mathrm{M}$ phosphate buffer ( $\mathrm{pH}$ 7.0) containing nonfat milk powder. Subsequently, resuspended in a solution of an $\mathrm{Ab}$ to the $\mathrm{Btt}$ toxin and in a solution of antirabbit $\mathrm{Ab}$ conjugated with fluorescein isothiocyanate (FITC-Ab), respectively. The particles alone and in bound complexes with the Btk toxin served as controls. All particles that bound the Btt toxin showed a significant shift in the peak of fluorescence to the right on the $x$ axis as compared with the nonspecific fluorescence from the control FITC-Ab complexes with particles in the absence of the toxin. There was also a slight shift to the right in the peak for some particles that bound the $B t k$ toxin, though not as much as with the bound complexes of the particles with the Btt toxin, which may be due to some cross-reactivity between the Btt and Btk toxins and the $\mathrm{Ab}$ they induced. This method is useful only for qualitative analysis, as most flow cytometers cannot detect very fine particles and accurate dose-response data cannot be obtained. Newer flow cytometers capable of analyzing particles $<2 \mu \mathrm{m}$ in effective diameter may be able to monitor the fate of bound $B t$ toxins and other proteins in environmental samples.

When free toxin from Btk was added to nonsterile soils, greater loss in larvicidal activity was detected after 234 days, the longest time evaluated, when the $\mathrm{pH}$ of soil unamended or amended to $6 \%(\mathrm{v} / \mathrm{v})$ with $\mathrm{K}$ was increased from 4.9 to 7.0 [62]. The experiments were conducted by adding the Btk toxin to three soils: soil naturally containing $\mathrm{K}$ but not $\mathrm{M}$ and unamended or amended with $\mathrm{M}$ or $\mathrm{K}$ as an internal control; soil naturally containing $\mathrm{M}$ and $\mathrm{K}$; and another soil naturally containing $\mathrm{K}$ but not $\mathrm{M}$. The persistence of the toxins was detected by insecticidal bioassay with the larvae of $M$. sexta. The toxicity varied with the type of the soil and its amendments with clays. Aqueous extracts from the soil amended or unamended with $\mathrm{K}$ were toxic to larvae $\left(\mathrm{LC}_{50}=\right.$ 61 to $111 \mathrm{ng} / 100 \mu \mathrm{l}$ of soil suspension) for 195 days whereas the toxicity was reduced in soils amended with $\mathrm{M}$ after 35 days $\left(\mathrm{LC}_{50}=104\right.$ to $\left.192 \mathrm{ng} / 100 \mu \mathrm{l}\right)$. The $\mathrm{pH}$ of the soils was higher $(5.8-7.3)$ in which the insecticidal activity was reduced than that of soils $(4.9-5.1)$ where the activity retained. The soils with a higher $\mathrm{pH}$ showed more biodegradation of the toxins as a high $\mathrm{pH}$ is favorable for microbial activity. These results demonstrated that insecticidal activity was retained when Btk toxin was incubated in soil, but the amount of retention varied with the type of soil, probably because of differences in the clay mineralogy and $\mathrm{pH}$ of the soils. Soils containing $\mathrm{M}$ have a better buffering capacity against changes in $\mathrm{pH}$ than soils without $M$ [58, 69]. These and previous studies confirmed that $B t$ toxins bound on clays or other surface-active particles $[61,63,64,70]$ could accumulate in soil and retain insecticidal activity. These results have importance when evaluating the potential risks associated with the release to the environment of transgenic plants and bacteria containing genes from subspecies of $B t$ that encode for active toxins.

The activity of free and clay-bound insecticidal proteins from Bti was evaluated against the mosquito, Culex pipiens L. [10]. The hydrolysis of the ICPs from Bti in the larval gut of Diptera results in four major proteins with a molecular mass $\left(\mathrm{M}_{\mathrm{r}}\right)$ of $27,65,128$, and $135 \mathrm{kDa}$. The synergistic interaction between the $25-\mathrm{kDa}$ protein (proteolytic product of the 27-kDa protein) and one or more of the proteins with a higher $M_{r}$ is responsible for toxicity. The equilibrium adsorption of the proteins on $\mathrm{M}$ and $\mathrm{K}$, homoionic to various cations, was rapid (<30 min for maximal adsorption) and increased with an increase in protein concentration until a plateau was reached (68 to $96 \%$ of the proteins was adsorbed). Adsorption was significantly lower on $\mathrm{K}$ than on $\mathrm{M}$ and was not significantly affected by the valence of the cation to which the clays were homoionic. Binding of the proteins decreased as the $\mathrm{pH}$ was increased from 6 to 11 , and there was 35 to $66 \%$ more binding in phosphate buffer at $\mathrm{pH}$ 
6 than in distilled water at $\mathrm{pH} 6$ or 7.2 . Only 2 to $12 \%$ of the adsorbed proteins were desorbed by two washes with water; additional washings desorbed no more proteins, indicating that the proteins were tightly bound. Formation of complexes of the proteins and clays did not alter the structure of the proteins, as indicated by SDS-PAGE of the equilibrium supernatants and desorption washes and by dot-blot ELISA of the complexes, which was confirmed by enhanced chemiluminescence Western blot analysis. Free and claybound toxins resulted in 85 to $100 \%$ mortality of $C$. pipiens. Persistence, as measured by mortality, of the bound toxins in nonsterile water after 45 days was significantly greater (mortality of $63 \% \pm 12.7 \%$ ) than that of the free toxins (mortality of $25 \% \pm 12.5 \%$ ), indicating that binding of the toxins on the clays reduced their susceptibility to biodegradation, as has been shown with the toxins of other subspecies of $B t[60,12]$. However the higher mortality with clay-bound toxins could have reflected greater ingestion by the mosquitoes, which are filter-feeders, of bound than of free toxins [71].

\subsubsection{Adsorption and Binding of the Toxin from Btk on Humic Acids and on Complexes of Clay-Humic Acids-Al hydroxypolymers}

The equilibrium adsorption and binding of the toxin from Btk on humic acids extracted from forest (Foresta Umbra, Sardegna) and cultivated (hop, sugar beet) soils and the insecticidal activity and biodegradation of the bound toxin were studied [70]. 75 to $85 \%$ of the toxin adsorbed at equilibrium was strongly bound, and the bound toxin was toxic to the larvae of $M$. sexta. The differences in total acidity and in content of phenolic group of the humic acids did not seem to be responsible for the differences in the amounts of toxin bound (about 45 to $80 \%$ ), after extensive washing with distilled water. The content of carboxyl groups and the degree of polymerization (i.e., the E4/E6 ratio) also did not appear to be responsible for the differential binding. The $\mathrm{LC}_{50}$ of bound toxin was comparable to that of free toxin, indicating that binding on the humic acids did not affect insecticidal activity. The biodegradability of the bound toxin was reduced, as it did not support the growth of mixed microbial cultures from soil, whereas the free toxin was readily utilized, in agreement with the results with free and clay-bound toxins from other subspecies of $B t$ and other surface-active particles in soil. Similarly, $c a$. $70 \%$ of the toxin from Btk adsorbed and bound on complexes of $\mathrm{M}$ humic acids-Al hydroxypolymers within the first hour, with maximal adsorption in $<8 \mathrm{~h}$ [72]. Adsorption on a constant amount of the complexes increased as the amount of toxin added increased, and the equilibrium adsorption isotherms were of the L-type. There was essentially no desorption of the toxin after extensive washing of the toxin-organomineral complexes with double distilled $\mathrm{H}_{2} \mathrm{O}$ and $1 \mathrm{M} \mathrm{NaCl}$. Free and bound toxins were active against the larvae of $M$. sexta.

These results showed that the toxin from Btk binds rapidly and strongly on complexes of montmorillonite-humic acids-Al hydroxypolymers. This is the first study in which organomineral complexes were used with $B t$ toxins. Organomineral complexes are presumably more representative of natural soils than clays and humic substances alone, and they have been suggested as a possible substitute for whole soil to predict the fate of biomolecules (e.g., proteins, DNA) in the soil environment [72]. Thus, many difficulties that can arise from the use of intact soil, such as interference of dissolved organic matter with colorimetric assays, changes in soil structure as a result of sterilization by autoclaving, and inhomogeneous interactions of biomolecules with soil surfaces, can be minimized. Furthermore, by comparing, under laboratory conditions, adsorption and desorption processes, the contribution of different surface-active soil particles can be evaluated, as can the effects of differences in organic carbon content, cationexchange capacity, specific external surface area, and expandability of the clays on the adsorption process in terms of maximal amounts adsorbed, optimal $\mathrm{pH}$, and mechanisms of adsorption. In this study, differences in these characteristics between the complexes did not appear to affect significantly the adsorption process. Nevertheless, the mechanisms by which toxins bound on particles kill susceptible larvae, especially as the bound toxins were more resistant to biodegradation than free toxins, are not known. The binding of proteins on clay and other surface-active particles is primarily by $\mathrm{H}$ bonds, and segments of the proteins are constantly detaching and reattaching [58]. Consequently, bound toxins could move from particles to receptors on the epithelium of the larval gut when an end of the toxins detaches from the particles, especially if the receptors have a higher affinity ("specific binding") for the toxins than the particles ("nonspecific binding") [58]. Also, $\mathrm{pH}$-dependent changes may be involved in the conformation of bound toxins, which may affect the relative susceptibility of their $\mathrm{C}$ and $\mathrm{N}$ termini to cleavage by proteases [73].

\subsection{Microbial Utilization of Free and Bound Toxins}

The binding of the toxins from various subspecies of $B t$ on surface-active particles (e.g., clays, humic acids) reduced their availability for microbial degradation, which was probably responsible for the persistence of the toxins in soil $[60,61,63,64,70,72]$. When the utilization of free and bound toxins by pure and mixed microbial cultures (including cultures preincubated on the toxins) was assessed, the free toxins were readily utilized as sole sources of carbon and/or nitrogen by both pure and mixed cultures, including soil suspensions, whereas the bound toxins were not utilized as a source of carbon, only slightly as a source of nitrogen, but did not support growth in the absence of exogenous sources of both available carbon and nitrogen. The insecticidal activity of bound toxins was retained after exposure to microbes, both in vitro and in soil, and even after alternately freezing-thawing or wetting-drying the soiltoxin complexes continuously for 40 days in nonsterile soil maintained at the $-33 \mathrm{kPa}$ water tension and room temperature.

Some possible mechanisms by which proteins, including Cry proteins, bound on clays resist utilization as nutrients, degradation or inactivation by microbes include the following: (i) there may be intercalation of swelling 2:1layer clays, such as $M$, which renders proteins inaccessible to proteolytic enzymes; (ii) terminal amino acid residues necessary for initiation of cleavage by peptidases may be involved in binding and, therefore, inaccessible; (iii) binding may so alter the conformation of proteins that the peptide bond may be nonsusceptible to peptidases; and (iv) substances in soil (e.g., ions, humic substances, other organic 
molecules) may bind on or become associated with clayprotein complexes and render the protein inaccessible [58]. The toxins only partially intercalated $\mathrm{M}$ (as determined by X-ray diffraction analysis), and their conformation (as indicated by infrared and immunological analyses and by electrophoretic mobility) was not changed by binding [61]. Therefore, bound toxins may have been protected from microbial activities by the inaccessibility of amino acid residues and, in the soil studies, by the binding of substances in soil on the clay-toxin complexes. Other proteins, peptides, amino acids, viruses, and DNA have also been shown to be protected against microbial degradation when bound on clays $[58,74-76]$.

In these studies with Cry proteins, in which the bound proteins were exposed to conditions that were more extreme than those that usually occur in soil in situ (e.g., microbes that utilize proteins readily and rapidly were enriched before adding to soil in microcosms incubated under optimal conditions of moisture and temperature, whereas soil in situ contains a diverse microbial community that is more oligotrophic and relies on numerous substrates for nutrients and in which environmental conditions fluctuate widely), the proteins were protected from microbial activities and remained insecticidal, confirming that the bound toxins persist and retain insecticidal activity in soil [12, 57, 61-64, 68].

In summary, the results showed that the toxins from $B t$ bound on surface-active particles were more resistant to the activities of microorganisms than free toxins, indicating that the toxins in $B t$ sprays and transgenic $B t$ biomass would not be present long in soil in a free state susceptible to biodegradation. Consequently, the toxins could accumulate and retain insecticidal activity when bound on such particles in soil. These results are important in evaluating the potential risks associated with the release to the environment of transgenic plants and bacteria containing cry genes from subspecies of Bt. This is especially relevant to transgenic organisms containing truncated toxin genes that code for active toxins rather than for inactive protoxins, as larvae that ingest the toxins do not require a high gut $\mathrm{pH}$ and appropriate proteases for solubilization and cleavage of the protoxins [3], which could reduce the host specificity of the toxins. Therefore, nontarget species could be susceptible to the toxins. Moreover, the accumulation of the toxins could also result in the selection and enrichment of toxin-resistant target species, as well as increasing the control of target pests. These and earlier studies with organic (humic acids) and inorganic (clays) soil particles [60, 61, 64, 70] support the general concept that the risks and benefits of genetically modified organisms and their products must be evaluated in extensive laboratory and field studies before their release to the environment.

\section{FATE AND EFFECTS OF B $t$ CORN AND OTHER B $t$ PLANTS IN SOIL ECOSYSTEMS:}

Genetic engineering offers the opportunity to develop plants with a variety of new traits that may be useful in, for example, pest control, improvement of crop yields, resistance to frost and drought, increased nutritional value of food products, sources of medical and industrial biomolecules, and degradation of a variety of persistent organic molecules, thereby facilitating bioremediation [77, 78]. However, the fate and effects of the novel genes encoding these traits in plants and the potential effects of their products on ecosystems continue to be of concern [79].

The repeated and large-scale cultivation of $B t$ crop plants and incorporation of their residues after harvest could result in the accumulation and persistence in soil of not only plant produced Cry proteins but also of cry genes, due to their binding on surface-active soil components [12, 26, 57, 62, $70,80-85]$. The release of DNA from plants, animals, and microorganisms can occur by lysis after their death [86-89], after infection of bacteria by bacteriophages [87, 89-94], and by active release of plasmid and chromosomal DNA by living bacteria $[91,95]$. Such extracellular DNA can attain concentrations that could result in horizontal gene transfer (HGT) by transformation. Thus, over long periods of time, HGT is probably important in enhancing both microbial diversity in an environment such as soil [96] and bacterial evolution [94, 97-101], as indicated in large-scale sequencing of bacterial genomes [102]. Numerous bacterial species have been reported to be capable of natural transformation and of active or passive release of DNA [78, 95, 99, 103]. The concept that extracellular DNA is rapidly degraded in soil $[104,105]$ has been challenged by studies that have shown that DNA is present in soil where free DNA or plant material had been deposited and to persist in nonsterile soil for several months [57, 75, 89, 93, 106-110]. Recombinant DNA was found in rhizosphere soil of transgenic potato plants, where it was apparently released by roots during plant growth and by pollen during flowering [111]. Plant roots provide microorganisms in the rhizosphere with large colonizable surface areas, and bacterial populations in the rhizosphere are presumably more stable than in bulk soil, as the result of the availability of nutrients and specific microniches [101]. Studies in situ have shown that HGT occurs primarily in niches characterized by high bacterial densities, indicating that the available nutrients enable bacteria to form localized dense aggregates (microcolonies), wherein the probability of transfer of DNA is high [78, 101]. In addition, DNA may be preserved in dead plant tissue, perhaps protected by cell walls, with retention of transforming capability for at least a few days [112]. The $c r y 1 A b$ gene derived from fields of $B t$ corn was detected in nearby streams and rivers and sometimes several kilometers downstream, indicating contamination by agricultural transgenic DNA, and the gene persisted for more than 21 and 40 days in surface water and sediment, respectively. In contrast, the Cry1 Ab protein was seldom detected in aquatic environments and only in trace amounts [113,114].

In 2008, the genetically modified (GM) crops were grown on a total of 125 million hectares of land in 25 different countries. The top eight GM-crop producing countries are the United States, Argentina, Brazil, India, Canada, China, Paraguay, and South Africa. The primary GM crop produced worldwide is soybean, which accounted for $53 \%$ of global biotech area in 2008, followed by maize $30 \%$, cotton $12 \%$, and canola $5 \%$. Insect-resistance based on $B t$ is the second major trait, besides herbicide-tolerance, used in commercial GM crops [115] could improve productivity. The cry genes from $B t$ have been inserted into numerous plant species, such as maize, cotton, potato, tomato, rice, eggplant, and canola, to produce their own Cry proteins. 


\subsection{Release and Fate of $B t$ Toxins in Root Exudates of Transgenic Bt Plants}

In contrast to cells of subspecies of B. thuringiensis, which express Cry proteins as protoxins, most transgenic $B t$ plants contain inserted truncated and genetically reorganized cry genes that encode active toxins. Studies were conducted to determine whether $B t$ toxin is released into rhizosphere soil in root exudates from $B t$ corn [30]. The rationale was that if the toxins are released from the tops of plants in pollen, are they also released from the bottom of the plants in root exudates? The caterpillars of monarch butterfly (Danaus plexippus L.) were killed after feeding on milkweed (Asclepias curassavica L.) that had been artificially contaminated with pollen from transgenic $B t$ corn that expressed the crylAb gene from Btk [27], and green lacewings (Chrysoperla carnea Stephens), insect predators of other insects were killed by ingesting European corn borers (Ostrinia nubilalis Hübner) reared on biomass of $B t$ corn $[46,47]$.

Surface-sterilized seeds of $B t$ corn and of the nearisogenic strain without the $c r y l A b$ gene were grown in sterile hydroponic culture and in sterile and nonsterile soil in a plant-growth room. Cry1 Ab protein $\left(\mathrm{M}_{\mathrm{r}}=66 \mathrm{kDa}\right)$, was evident on SDS-PAGE after 7 and 15 days only in the exudates from $B t$ corn, although several protein bands of smaller $\mathrm{M}_{\mathrm{r}}$ were seen in exudates from both $B t$ and non- $B t$ corn. The presence of toxin in the exudates from $B t$ corn was confirmed by immunological Western Blot assay (Lateral Flow Quickstix, EnviroLogix, Portland, ME; detection limit $<10 \mathrm{ppb}$ toxin) and verified as being biologically active in an insecticidal bioassay using larvae of $M$. sexta $[62,64]$. Larvae placed on medium containing exudates from $B t$ corn stopped feeding and began to die after 2 to 3 days and had a mortality of 90 to $95 \%$ after 5 days. There was no immunological reaction or larval mortality with the exudates from non-Bt corn. After 25 days of growth, when the hydroponic medium was no longer sterile, as demonstrated by streaking it on various microbiological media, the $66 \mathrm{kDa}$ band disappeared and several new protein bands of smaller $\mathrm{M}_{\mathrm{r}}$ appeared, and the immunological and larvicidal assays were negative, indicating that microbial proteases had hydrolyzed the toxin. The supernatants of aqueous suspensions of soil samples from the rhizosphere of sterile seedlings of $B t$ corn that had been transplanted into either sterile or nonsterile soil gave positive immunological and larvicidal assays even after 25 days of growth (e.g., 100\% mortality) whereas they were negative for non-Bt corn. Moreover, particles of rhizosphere soil placed directly on the bioassay medium caused mortality comparable to the supernatants. These results confirmed earlier findings with purified toxins and surface-active particles that the toxins bind rapidly on soil particles and that the bound toxins retain larvicidal activity and are protected by binding against biodegradation $[60-64,70]$. Although some toxin was probably released from sloughed and damaged root cells, the major portion was derived from root exudates, as there was no discernible root debris when plants were grown for 25 days in hydroponic culture [30].

To estimate the importance of the clay mineralogy and other physicochemical characteristics of soil on the effects of $B t$ toxins released in root exudates in the activity and ecology of microbes in soil, studies were conducted with $B t$ corn grown in nonsterile soils amended with various concentrations of $\mathrm{M}$ or $\mathrm{K}$ in a plant-growth room and in soils in the field $[31,82,83]$. The insecticidal protein encoded by the $c r y l A b$ gene from $B t$ was released in root exudates from 13 hybrids of transgenic $B t$ corn, representing three different transformation events (Bt11, MON810, and 176), during 40 days of growth in soil amended to $0,3,6,9$, or $12 \%(\mathrm{v} / \mathrm{v})$ with $\mathrm{M}$ or $\mathrm{K}$ in a plant-growth room and from plants grown to maturity in the field. The presence of the toxin in rhizosphere soil was determined immunologically and in larvicidal assays with the larvae of $M$. sexta. All samples of soil with $B t$ corn were toxic, with mortality ranging from 25 to $100 \%$ on day 10 and increasing to 88 to $100 \%$ on day 40 . In addition, the size and weight of surviving larvae exposed to soils from $B t$ corn were significantly lower ( $c a$. 50 to $92 \%$ lower) than those exposed to soils from non- $B t$ corn or without plants, and these larvae usually died after an additional 2 to 3 days. No toxin and no mortality in any soils was detected with the near-isogenic non-Bt corn counterparts or without plants. The larvicidal activity was generally higher in soil amended with $\mathrm{M}$ than with $\mathrm{K}$, probably because $\mathrm{M}$, a swelling 2:1, Si:Al, clay mineral with a significantly higher cation-exchange capacity (CEC) and specific surface area (SSA) than $\mathrm{K}$, a non-swelling 1:1, $\mathrm{Si}: \mathrm{Al}$, clay, bound more toxin in the root exudates than $\mathrm{K}$ $[58,61,64,66]$. Nevertheless, the mortality in all soils, unamended or amended with $\mathrm{M}$ or $\mathrm{K}$, was essentially the same after 40 days, indicating that over a longer time, the persistence of larvicidal activity appeared to be independent of the clay mineralogy and other physicochemical characteristics of the soils. However, the increase in larvicidal activity between day 10 and day 40 indicated that the toxin in the root exudates was concentrated when adsorbed on surface-active components of the soils. The immunological and larvicidal assays of soil from the rhizosphere of the different hybrids of $B t$ corn grown in the field were also positive, even in soil collected after the first frost from plants that had been dead for several months, whereas they were negative for all non-Bt corn hybrids. Although the larval mortality in rhizosphere soil from some plants of field-grown $B t$ corn was only $38 \%$, the size and weight of the surviving larvae were reduced by 40 to $50 \%$ when compared with soil from non-Bt corn or without plants, and the larvae died after a few more days.

There were no discernable or consistent differences in exudation of the toxin, based on mortality, weight of surviving larvae, and immunology between hybrids derived from different transformation events and regardless of their growth in the plant-growth room or in the field. These in vitro and in situ studies showed again that toxin released in root exudates accumulated in soil by binding to surfaceactive soil particles, thus protecting the toxin from biodegradation and retained insecticidal activity $[57,60]$ for at least 180 days $[29,83]$.

Transgenic Bt corn transformed with event MON863, which expresses the cry3Bbl gene from B. thuringiensis subsp. kumamotoensis (Btku) to control the corn rootworm complex (Diabrotica spp.), was released for commercial use in 2003. The concentration of the Cry3Bb1 protein in tissues of this $B t$ corn was significantly higher $(81 \mu \mathrm{g} / \mathrm{g}$ of leaves, 41 $\mu \mathrm{g} / \mathrm{g}$ of roots) than in other transgenic $B t$ corn lines (e.g., 
events 176, Bt11, MON810) expressing the Cry1 Ab protein (3 to $10 \mu \mathrm{g} / \mathrm{g}$ of leaves, negligible in roots) [116].

To determine whether the Cry3 $\mathrm{Bb} 1$ protein is released in root exudates of $B t$ corn, two hybrids of corn, DeKalk DKC46-23 (event MON863) containing a truncated synthetic version of a gene from Btku coding for the expression of the anticoleopteran $\delta$-endotoxin, Cry $3 \mathrm{Bb} 1$, and its near-isogenic nongenetically modified variety, DKC4626 , were grown in sterile hydroponic culture and nonsterile soil [117]. The Cry3Bb1 protein was released in root exudates in sterile hydroponic culture $(7.5 \pm 1.12 \mathrm{ng} / \mathrm{ml}$ after 28 days of growth) and in nonsterile rhizosphere soil throughout growth of the plants $(2.2 \pm 0.62 \mathrm{ng} / \mathrm{g}$ after 63 days of growth), as determined by Western blots and ELISA (ImmunoStrip; Agdia, Elkhart, IN), similar to the Cry1 Ab (in $B t$ corn and rice) and Cry3A (in $B t$ potato) proteins [26, $30,31,82-84]$, albeit at lower levels. However, in rhizosphere soil unamended with $B t$ corn biomass, the Cry3Bb1 protein solely released in root exudates was detected only for 14 days. The persistence of the protein in soil amended to 3 or $6 \%(\mathrm{v} / \mathrm{v})$ with $\mathrm{K}(3 \mathrm{~K}$ and $6 \mathrm{~K}$ soils) or $\mathrm{M}$ (3M and $6 \mathrm{M}$ soils) and with $1,3,5$, or $10 \%(\mathrm{w} / \mathrm{w})$ of ground biomass of $B t$ corn expressing the Cry3 $\mathrm{Bb} 1$ protein and incubated at $25 \pm 2^{\circ} \mathrm{C}$ at the $-33 \mathrm{kPa}$ water tension for 60 days was dependent on the type and amount of clay mineral present and on the $\mathrm{pH}$ of the soils. Soils were analyzed for the presence of the protein every 7 to 10 days with a Western blot assay and verified by ELISA (Agdia). Persistence of the protein was greater with the higher concentration of $\mathrm{K}$ but lower with the higher concentration of $\mathrm{M}$. Persistence decreased when the $\mathrm{pH}$ of the $\mathrm{K}$-amended soils was increased from $c a .5$ to $c a .7$ with $\mathrm{CaCO}_{3}$ : the protein was not detected after 14 and 21 days in the $\mathrm{pH}$-adjusted $3 \mathrm{~K}$ and $6 \mathrm{~K}$ soils, respectively, whereas it was detected after 40 days in the $3 \mathrm{~K}$ and $6 \mathrm{~K}$ soils not adjusted to $\mathrm{pH} 7$. The protein was detected for only 21 days in the $3 \mathrm{M}$ soil and for 14 days in the $6 \mathrm{M}$ soil, which were not adjusted in $\mathrm{pH}$.

In general, the protein persisted in the clay-unamended, $3 \mathrm{~K}$, and $6 \mathrm{~K}$ soils for $\mathrm{ca} .40$ days, whereas it persisted in the $3 \mathrm{M}$ and $6 \mathrm{M}$ soils for only 21 days, regardless of the amount of $B t$ biomass added. Although the addition of increasing amounts of $B t$ biomass significantly increased the amount of the protein detected initially and during the first 7 and 14 days of incubation, the differences in the amount of the protein detected in soils to which different concentrations of biomass had been added were generally not significant after 21 days. The addition of $B t$ biomass also significantly increased the $\mathrm{pH}$ of the soils, which enhanced the biodegradation of the protein, probably as the result of increased microbial activity. These results indicate that the Cry3Bb1 protein does not persist or accumulate in soil and is degraded rapidly. In addition to the increase in microbial activity in soils with a $\mathrm{pH}$ near neutrality, adsorption of Cry $1 \mathrm{Ab}$, Cry3Aa, and Cry4 proteins on clays decreased with an increase in $\mathrm{pH}[10,61,62,72,118]$, which also rendered a portion the proteins more susceptible to biodegradation. Similarly, Wang et al [119] reported that the Cry1 Ab protein from biomass of $B t$ rice degraded faster in an alkaline soil (half-life of 11.5 days) than in an acidic soil (half-live of 34.3 days). Free Cry1 Ab protein (i.e., not bound on clays or humic substances) was readily utilized as a sole source of carbon and/or nitrogen by pure and mixed cultures of microbes, whereas the bound protein was resistant to utilization, especially as a source of carbon [60, 70, 72]. These results were similar to those reported by Ahmad et al [120], who found no detectable Cry3Bb1 protein in soil planted with $B t$ corn for three consecutive seasons in Manhattan, KS, USA, and concluded that the Cry3Bb1 protein released in root exudates or from decaying plant residues does not persist and is rapidly degraded in soil.

In conclusion, despite the low level of the Cry3Bb1 protein in the plant biomass used in this study, in contrast to higher concentration reported by others [121], the major result of this study was that the Cry3Bb1 protein does not accumulate in soil. The Cry $3 \mathrm{Bb} 1$ protein is released in root exudates and from decaying plant residues of $B t$ corn, but the protein does not persist in soil and is degraded rapidly, suggesting that it probably poses relatively little ecological or environmental risk. The importance of $\mathrm{pH}$ and other physicochemical, as well as biological, characteristics of soil in the persistence of this and various other Cry proteins in soil needs to be further determined, especially to explain the reported differences in the persistence of the different proteins.

The release of different Cry proteins in the root exudates of various $B t$ plants was evaluated [26]. Cry1 Ab protein from corn (Zea mays L.) and rice (Oryyza sativa L.), Cry3A protein from potato (Solanum tuberosum L.), and Cry3Bb1 protein from corn were released in root exudates, whereas the Cry1Ac protein was not released in root exudates from canola (Brassica napus L.), cotton (Gossypium hirsutum L.), and tobacco (Nicotiana tabacum L.). Nonsterile soil and sterile hydroponic solution in which $B t$ corn, rice or potato had been grown were immunologically positive for the presence of the Cry proteins, and the soil and solution from $B t$ corn and rice, were toxic to the larva of $M$. sexta, and from $B t$ potato, to the larva of $L$. decemlineata. No toxin was detected immunologically or by larvicidal assay in soil or hydroponic solution in which $B t$ canola, cotton, or tobacco, as well as all near-isogenic non-Bt plant counterparts or no plants, had been grown.

The size and weight of surviving larvae of $M$. sexta exposed to soil or hydroponic solution from $B t$ corn or rice were significantly lower ( $c a .82$ to $90 \%$ lower; $P<0.05$ ) than those exposed to soil or solution from other $B t$ or non$B t$ plants or without plants, and these larvae usually died after an additional 2 to $3 \mathrm{~d}$. Although some differences in larval weights were apparent among treatments, these differences were not statistically significant when compared with the range of weights of control larvae, which showed an average coefficient of variation of $23.4 \%$. The major criterion of the effects of the toxins was percent mortality, and sub-lethal effects were evaluated only on the few surviving larvae.

There were apparent differences in exudation of the proteins (as evaluated by mortality, weight of surviving larvae, and immunologically) between plant species: exudates from $B t$ corn were more toxic than those from $B t$ rice and potato. No green fluorescent protein (GFP) was detected in hydroponic solutions from canola and tobacco genetically modified to express GFP or both GFP and Cry1Ac protein. Although some Cry proteins were probably released from sloughed and damaged root cells of $B t$ corn, 
rice, and potato in soil, the major portion was derived from root exudates, as there was no discernable root debris when plants were grown in hydroponic culture, and no Cry proteins from $B t$ canola, cotton, or tobacco were detected when grown in soil where some damage probably occurred. Moreover, the Cry proteins were detected in the tissues of all $B t$ plants. These data again demonstrate that, in addition to the introduction to soil of Cry proteins in plant biomass and pollen, they will also be released in root exudates during the entire growth of some $B t$ plants.

The reasons for the release of Cry proteins in the root exudates of $B t$ corn, rice, and potato but not of $B t$ canola, cotton, and tobacco are not known. The methods of transformation of the cry genes, somaclonal variation, differences in level of protein expression [122] [although all species had the cauliflower mosaic virus (CaMV) $35 \mathrm{~S}$ promoter, except rice, which had the ubiquitin promoter from maize], or location of the endoplasmic reticulum relative to the plasma membrane (in corn, this appears to be a close relation) may be involved [12]. Although Cry1Ab and Cry1Ac proteins differ in some aspects, the differences are apparently small, as their insect targets are similar and they cross-react with antibodies to each [64]. Nevertheless, these and other differences may be responsible for release of the Cry1Ab protein and the lack of release of the Cry1Ac protein in root exudates [26]. The reasons for the disparity in the release of Cry toxins in root exudates need to be determined on a case-by-case plant and toxin basis, as these disparities have relevance to other $B t$ plants, especially as at least 26 plant species [123], including corn, cotton, potato, canola, rice, broccoli, peanut, eggplant, and other crop species, have been modified to express Cry proteins. Further studies on the physiology and anatomy of the roots of these transgenic plants, as well as of the environmental effects of these toxins, are obviously necessary.

3.2. Bt Toxin (Cry1Ab Protein) Released from Root Exudates and Biomass of $B t$ Corn has no Effect on Earthworms, Nematodes, Protozoa, Bacteria, and Fungi in Soil

The effects of root exudates and biomass from $B t$ and non- $B t$ corn on earthworms and other organisms in soil was determined [81]. Fifteen plastic pots $(18 \mathrm{~cm}$ dia., $21 \mathrm{~cm}$ deep; five each for Bt corn, non-Bt corn, and with no plants) were each filled with ca. $4.5 \mathrm{~kg}$ of soil, and 20 medium-size earthworms (Lumbricus terrestrism L.), with well developed clitellum, purchased from Carolina Biological Supply Company (Burlington, North Carolina), were placed in each pot and kept overnight in the dark at $24 \pm 28^{\circ} \mathrm{C}$ when the worms entered the soil. The total count of the organisms in the soil was estimated before the earthworms were introduced. Seeds of Bt corn (NK4640Bt) and of isogenic non-Bt corn were planted (three seeds per pot), and after 40 days of growth in a plant-growth room $\left(26 \pm 2{ }^{\circ} \mathrm{C}, 12 \mathrm{~h}\right.$ lightdark cycle; soil water content maintained at $c a$. field capacity, and no water stress was apparent in the plants), the plants were gently removed and rhizosphere soil was collected by gently shaking the roots to dislodge adhering small clumps of soil. $500 \mathrm{~g}$ of soil amended with $1 \%$ (w/w) of ground, air-dried biomass (leaves, stems, and roots) of $B t$ corn (NK4640Bt) (Cry1Ab) or isogenic non-Bt (NK4640) corn was placed into each of five jars $(10 \mathrm{~cm}$ dia., $16 \mathrm{~cm}$ deep), and five medium-size earthworms (L. terrestris L.) were added to each jar. Two control jars received no biomass. All jars were kept in a plant-growth room for 45 days with the soil moisture maintained at $c a$. field capacity. Casts produced by the earthworms were collected from all pots and jars. After incubation, the earthworms in the pots and jars were counted and their weight determined. Three representative worms from each pot and two from each jar were dissected, and the gut contents were analyzed for the presence of Cry1 Ab protein by immunological and larvicidal assays. Nematodes were extracted from soil by the Baermann technique [124]. Total numbers of culturable protozoa were estimated by a most-probable number (MPN) method using agar plates [125]. The colony-forming units (CFU) of culturable bacteria and fungi were estimated on soil extract agar and Rose Bengal-streptomycin agar, respectively [125]. Aqueous supernatants of the soils were analyzed immunologically for the Cry $1 \mathrm{Ab}$ protein by Western blot using Lateral Flow Quickstix (EnviroLogix) $[30,31]$. The larvicidal activity of the soils was determined with the larvae of $M$. sexta [62].

There were no significant differences in the percent mortality and weight of earthworms after 40 days in soil planted with $B t$ or non- $B t$ corn or after 45 days in soil amended with biomass of $B t$ or non- $B t$ corn. The toxin was present in the guts and casts of earthworms in soil planted with $B t$ corn or amended with biomass of $B t$ corn, but it was not detected in guts and casts of worms in soil planted with non- $B t$ corn or amended with biomass of non- $B t$ corn. The toxin was cleared from the guts within 2 to 3 days after placing the worms in fresh soil. There were no significant differences in the CFU of culturable bacteria, including actinomycetes, and fungi and in the numbers of protozoa and nematodes between rhizosphere soil of $B t$ and non- $B t$ corn or between soil amended with biomass of $B t$ and non- $B t$ corn.

Therefore, the Cry1 $\mathrm{Ab}$ protein in root exudates and biomass of $B t$ corn did not appear to be toxic to earthworms, nematodes, protozoa, bacteria, and fungi in soil. The presence of the toxin in the guts and casts of earthworms confirmed that the toxin released in root exudates and from transgenic biomass was bound on surface-active particles in soil, which protected the toxin from biodegradation, even in such a physically- (e.g., peristalsis) and biologically-active environment as the gut of worms, as has also been observed with purified toxin. However, these results could be considered as being preliminary, as only one species of earthworm and only total numbers of culturable bacteria, fungi, protozoa, and nematodes were evaluated. More detailed studies on the composition and diversity of these groups of organisms are necessary (using e.g., denaturinggradient and temperature-gradient gel electrophoresis, single-strand conformation polymorphism, and/or the BIOLOG system for bacteria; speciation for fungi; nutritional groups for protozoa and nematodes) to confirm the absence of effects of the Cry1 Ab and other Cry proteins on biodiversity in soil.

\subsection{Microbiostatic and Microbicidal Activity of $B t$ Toxins}

The microbiostatic and microbicidal activity against a variety of pure and mixed cultures of bacteria, fungi, and 
algae of varying concentrations of $B t$ toxins, free or bound on M-Ca, was examined [126]. The insecticidal toxins from B. thuringiensis subsp. kurstaki (Btk; antilepidopteran), morrisoni strain tenebrionis (Btt; anticoleopteran) and israelensis (Bti; antidipteran) did not affect the growth of a variety of bacteria ( 8 gram-negative, 5 gram-positive, and 1 cyanobacterium), fungi (2 Zygomycetes, 1 Ascomycete, 2 Deuteromycetes, and 2 yeasts), and algae (primarily green and diatoms) in pure and mixed cultures as determined by dilution, disk-diffusion, and sporulation assays with purified and clay-bound toxins. The ICPs from Btk and Bti, either free or bound on clay, had no antibiotic effect on various gram-positive bacteria. No fungistatic activity against mycelia and spores, and no inhibitory activity to algae, in pure or mixed cultures was observed with toxins from $B t k$, $B t t$, and Bti either in free or bound state [126]. By contrast, antibiotic activity of the toxins from Btk and Btt against Micrococcus auranticus, Micrococcus luteus, Erwinia carotovora, and Streptomyces chrysomallus has been reported [127-130]. Although the results of most in vitro studies are the same as those observed in nonsterile soil, none of the studies evaluated changes in the composition of mixed cultures. The effect of these toxins on the biodiversity of the microbiota in soil is probably complex and needs to be scrutinized further.

\subsection{Release of Recombinant Proteins Other than Cry Proteins in Root Exudates from Transgenic Tobacco and their Effect on Microbes and Enzymatic Activities in Soil}

Major concerns with genetically-modified crops are that they may pose a risk to the environment, especially to soil, may contaminate other crops, and their products may enter the food chain [84, 131-134]. The release of human serum albumin (HSA), ß-glucuronidase (GUS), glycoprotein B (gB) of cytomegalovirus (CMV), and green fluorescent protein (GFP) in the root exudates of transgenic tobacco plants containing the genes for these proteins was evaluated [135].

HSA is the most abundant protein in the circulatory system of human beings and constitutes about $60 \%$ of the total protein in the blood. It transports fatty acids and binds with a variety of drugs and metabolites and, therefore, is potentially important as a plasma expander, stabilizing agent, drug delivery protein, and an adjuvant for novel drugs. Currently, HSA is prepared primarily by fractionation of donated human blood plasma and is used in plasmaphoresis; fluid replacement; treatment of burns, traumatic shock, and diuretic-resistant edema; and for some surgical patients [136]. However, this fractionation process is associated with a high risk of the HSA becoming contaminated by pathogens, such as the hepatitis virus, HIV, or other bloodborne diseases. Other methods of producing HSA involve using microbial, plant, or animal systems, but a major concern with HSA is that its form must assemble in the same manner as in human beings to retain its functionality [137]. Plants offer a suitable alternative to microbial or animal expression of proteins of pharmaceutical importance, because of their presumed inexpensive production costs and lack of pathogens [138]. Another advantage of using plants for expression is that they have the post-translational ability to fold and assemble proteins correctly, in comparison with prokaryotes [137, 139]. Sijmons et al, [140] initially showed that recombinant HSA can be produced in leaves of tobacco, potato tubers, and suspension cells of tobacco.

GUS is a hydrolase that catalyzes the cleavage of terminal glucuronic acid, B-linked to mono-, oligo-, or polysaccharides or phenols $[135,141]$. In microorganisms, e.g., Escherichia coli, GUS functions in carbohydrate and energy metabolism while in animals, it is present in virtually all tissues and is involved in stepwise degradation of glycosamino-glucuronides and release of active hormones from steroid hormone-glucuronide conjugates [142]. GUS is widely used as a marker in transgenic plant research as the enzyme can be detected by both cytochemical and spectrophotometric assays. Corn was the first plant to be commercialized for the production of GUS, an industrial product frequently used in laboratory research as a 'marker' in gene regulation and as a diagnostic reagent [143, 144]. The activity of GUS is dependent on the plants growth stage, so it has also been used to study the activity of promoters in different plant tissues at different stages of development. The GUS activity is more in the younger regions of the plant organs than in mature tissues [145]. In addition, fluorometric detection of GUS, using methyl umbelliferone $\beta$-glucuronide (MUG) as a substrate, is extremely sensitive [146]. The gene for GUS is absent in plant tissue, and Agrobacteriummediated transformation is used to incorporate the gene, which is present in one or more copies per plant genome [146, 147]. High levels of GUS are observed in cancer patients and are probably a consequence of disease rather than a cause. In most normal tissues, such as liver, GUS is confined to lysosomes and the smooth endoplasmic reticulum, but in tumor tissue, GUS is partly localized in extracellular space, due to lysosomal release from acute and chronic inflammatory cells and disintegrating tumor cells [148]. This increased activity of GUS in extracellular space makes GUS accessible to glucuronide pro-drugs, which are cleaved by GUS to release the active drug [149]. Currently, anticancer glucuronide pro-drugs are being tested to take advantage of this phenomenon. It is hoped that the use of glucuronide pro-drugs as targeted drug delivery systems will become a superior form of cancer therapy [150].

$\mathrm{gB}$ is a major component of the envelope of human cytomegalovirus (HCMV), a causal agent of herpes blisters and chicken pox/shingles, and a major target of neutralizing antibodies that develop after natural infection [151, 152]. As an immunologically important viral surface protein, $\mathrm{gB}$ has a major role in at least one of the steps in viral attachment to and infection of cells [153]. $\mathrm{gB}$ is present in abundance on the surface of the HCMV and is a candidate of prime significance in the development of a subunit vaccine. The plant system adequately mimics post-translational modifications to produce structurally-functional $\mathrm{gB}$ and, hence, offers a unique opportunity for the production and oral delivery of a subunit vaccine for HCMV [154].

GFP, a spontaneously fluorescent protein isolated from the jelly fish, Aequorea victoria, transduces the blue chemiluminescence of another protein, aequorin, into green fluorescent light by energy transfer [155]. GFP can also serve as a gene monitoring system that can be used to study the introgression of transgenes into wild relatives through hybridization, backcrossing, and transgene escape [156, 157]. 
The release in root exudates of HSA, GUS, gB, and GFP from genetically-modified transgenic tobacco expressing the genes for these proteins was determined in hydroponic culture and nonsterile soil. GUS, gB, and GFP were expressed in the plant but were not released in root exudates, whereas HSA was both expressed in the plant and released in root exudates, as shown by a $66.5 \mathrm{kDa}$ band on SDS-PAGE and Western blot and confirmed by ELISA. Root exudates from GUS- and gB- plants showed no bands that could be attributed to these proteins on SDS-PAGE, and root exudates from GFP plants showed no fluorescence. The concentration of HSA in extracts of root exudates and plant biomass and in soil was estimated to be $0.021 \mathrm{ng} / \mathrm{ml}, 0.087 \mathrm{ng} / \mathrm{ml}$, and 0.049 $\mathrm{ng} / \mathrm{g}$, respectively. There were no significant differences in the number of culturable bacteria, fungi, chitin utilizers, protozoa, denitrifiers, and oxidizers of ammonia and nitrite or in the activities of selected enzymes between the rhizosphere soil of genetically unmodified and HSA tobacco. Microbial and enzymatic assays were done only on soil in which HSA tobacco and unmodified tobacco, or no tobacco, had been grown, as GUS, gB, and GFP were not released in root exudates $[59,135]$.

The release of HAS, but not of GUS, gB, and GFP, in the root exudates of transgenic tobacco was similar to the results obtained with the Cry proteins from transgenic plants containing cry genes from subspecies of $B t: e . g$, the Cry $1 \mathrm{Ab}$, Cry $3 \mathrm{~A}$, and Cry3Bb1, but not the Cry1Ac, proteins were released in root exudates of $B t$ plants in sterile hydroponic culture, in sterile and nonsterile soil in a plantgrowth room, and in soil in the field under natural conditions $[26,30,31,84]$. The reasons for the release of only HSA and not of GUS, gB, and GFP in root exudates of transgenic tobacco are not known. The variations in the release of proteins in root exudates need to be explained and more detailed studies on the composition of the groups of organisms studied are necessary to confirm that HSA has no effect on the diversity and activity of the soil microbiota.

HSA, GUS, and Cry3Bb1 protein adsorbed and bound rapidly on the clay minerals, $K$ and $M$ [59]. With the increase in protein concentration, the adsorption increased, reaching plateau. Maximum adsorption and binding occurred with the Cry $3 \mathrm{Bb} 1$ protein, of which there was no desorption: $6.7 \pm 0.21 \mu \mathrm{g}$ adsorbed and bound $\mu \mathrm{g}^{-1}$ of $\mathrm{M} ; 2.1 \pm 0.39 \mu \mathrm{g}$ adsorbed and bound $\mu \mathrm{g}^{-1}$ of $\mathrm{K}$. With GUS, $2.2 \pm 0.29 \mu \mathrm{g}$ adsorbed and $1.7 \pm 0.21 \mu \mathrm{g}$ bound $\mu \mathrm{g}^{-1}$ of $\mathrm{M} ; 1.5 \pm 0.28 \mu \mathrm{g}$ adsorbed and $1.0 \pm 0.03 \mu \mathrm{g}$ bound $\mu \mathrm{g}^{-1}$ of $\mathrm{K}$. HSA was adsorbed and bound the least: $1.2 \pm 0.04 \mu \mathrm{g}$ adsorbed and $0.8 \pm 0.05 \mu \mathrm{g}$ bound $\mu \mathrm{g}^{-1}$ of $\mathrm{M} ; 0.4 \pm 0.05 \mu \mathrm{g}$ adsorbed and $0.4 \pm 0.03 \mu \mathrm{g}$ bound $\mu \mathrm{g}^{-1}$ of $\mathrm{K}$. However, X-ray diffraction analyses indicated that only HSA intercalated $\mathrm{M}$, and none of the proteins intercalated $\mathrm{K}$, a nonswelling clay. Simultaneously, relative utilization of bound and free proteins by microbes and enzymatic activity of bound and free GUS was studied. When bound, the proteins were not utilized for growth by mixed cultures of soil microorganisms, whereas the cultures readily utilized the free (i.e., not adsorbed or bound) proteins as sources of carbon and energy. The enzymatic activity of GUS was significantly enhanced when bound on the clay minerals. These results depicted that recombinant proteins expressed by transgenic plants could persist and function in soil after release in root exudates and from decaying plant residues as the result of the protection provided against biodegradation by binding on clay minerals.

\section{FIELD TRIALS WITH BT CORN}

\subsection{In Situ Field Studies of Microbial Populations and Enzyme Activities in Soil Under Transgenic Corn Expressing Cry Proteins from $B t$}

The effects of transgenic plants on microorganisms can be studied by monitoring levels of microbial populations, taxonomic groups, or microbe-mediated processes. As enzymes in soil are important for the growth of microorganisms (e.g., decomposition of organic residues, cycling of nutrients, formation of organic matter and soil structure), they are probably an indicator of overall microbial activity in soil [158].

Most studies have suggested that $B t$ plants cause only minor changes in the structure of microbial communities in soil, and the changes are often transient [159-163]. Other studies have shown no apparent deleterious effects of Cry proteins released by $B t$ plants in root exudates or from biomass of $B t$ plants incorporated into soil on microbial communities or representative enzymes $[29,70,72,81,115$, $117,126,164-169]$. Studies using culture-independent methods reported minor or no Bt-specific effects on soil microorganisms, and the age and type of plant and the type and texture of soil seemed to be the major factors affecting bacterial diversity [159, 170-172]. Few or no effects of $B t$ plants expressing Cry proteins were found on nontarget invertebrates in soil, such as earthworms [81, 85, 173], collembolans [173-177], isopods [178-180], mites [177, $181]$, nematodes $[81,182]$, and snails $[183,184]$. In contrast, several studies have indicated that $B t$ plants affect microbial communities [185-187], the activities of some enzymes [167, $168,188]$, and some microbe-mediated processes and functions in soil [169, 185, 189].

The effects in soil of genetically modified $B t$ corn expressing Cry $1 \mathrm{Ab}$ (events Bt11 and MON810) or Cry3Bb1 (event MON863) proteins on: (i) microbial diversity, using techniques of dilution-plating, most probable numbers (MPN), and polymerase chain reaction-denaturing gradient gel electrophoresis (PCR-DGGE); (ii) the activity of some enzymes involved in the degradation of plant biomass; and (iii) the persistence and larvicidal activity of the Cry proteins were evaluated during 4 consecutive years, from 2003 through 2006, of corn cultivation under field conditions at the Rosemount Experiment Station of the University of Minnesota [29]. Four transgenic Bt corn varieties (Novartis N45-A6, Novartis Attribute GSS-0966, and Pioneer 38A25), that express the Cry1 Ab protein toxic to the European corn borer (O. nubilalis), and DeKalb DKC46-24 that expressed the Cry3Bb1 protein toxic to the corn rootworm complex (Diabrotica spp.) were compared with their near-isogenic, non- $B t$ varieties (N45-T6, PrimePlus, 38A24, and DKC4628), respectively. DKC46-23 (Cry3Bb1) and DKC46-26 (near-isogenic) varieties were planted in 2003, but they were unavailable in subsequent years. DKC46-24 was commercially available only with a seed-applied insecticide (Poncho 1250) and was, therefore, applied to the seed of the DKC46-28 control before planting. Sweet corn varieties (Attribute GSS-0966 and Prime Plus) were not planted in 2005 and 2006, but soil planted to these sweet corn varieties 
in previous years was analyzed before (April 2005) and after (November 2005) planting with non-Bt corn to estimate the persistence in soil of the Cry1 Ab protein. In 2006, Pioneer $38 \mathrm{~A} 26$ and 38A81 were used, because 38A25 was no longer in production. Pioneer $38 \mathrm{~A} 26$ has a genetic background similar to 38A25. These eight treatments were randomized in a complete block design with four replicates each on $40 \mathrm{~m} \times$ $40 \mathrm{~m}$ adjacent plots separated by $20 \mathrm{~m}$ of non- $B t$ corn for a total of 32 plots. The varieties were planted in the same plots in all $4 \mathrm{y}$. Mineralogically, the soils contain quartz, feldspars, amphiboles, some well crystallized mica-illite, low amounts of chlorite and kaolinite, and no smectites or other swelling clays. Other details on the physicochemical characteristics of soils are given in Icoz et al [29].

Soils were collected randomly from a depth of 3 to $15 \mathrm{~cm}$ from the inner $20 \mathrm{~m} \times 20 \mathrm{~m}$ of each plot and immediately placed on dry ice in August 2003, August 2004, three times in 2005 (before planting [April], midseason [August], and after harvest [November]), and two times in 2006 (before planting [April] and after harvest [October]) from each of the 32 plots and sent to New York University (NYU) on dry ice. Soils adhering to the root systems of decomposing corn plants were sampled before tillage (April), from growing plants (August, except in August 2003, when bulk rather than rhizosphere soil was sampled), or from harvested plants (October and November). Two samples were taken from each plot; each sample was a subsample of pooled soil from three corn root systems separated by $>2 \mathrm{~m}$ from each other. The samples were immediately stored at $-20^{\circ} \mathrm{C}$ on receipt at NYU and analyzed for microbial populations, enzyme activities, $\mathrm{pH}$, water content, presence of the Cry1 $\mathrm{Ab}$ and $\mathrm{Cry} 3 \mathrm{Bb} 1$ proteins, and larvicidal activity of the Cry $1 \mathrm{Ab}$ protein. Because no consistent significant differences in the numbers of microorganisms and activities of enzymes between soils of $B t$ and non- $B t$ corn were observed and funds and personnel were limited, only two soil samples from each block were analyzed for $\mathrm{pH}$, total bacteria and fungi, and activities of dehydrogenases and proteases in October 2006. Counts of colonies of total culturable aerobic bacteria (including actinomycetes), gram-negative bacteria, chitinand cellulose utilizing organisms, and fungi were determined using the spread-plate technique to inoculate four replicate agar plates per dilution. Protozoa and nitrifying and denitrifying organisms were evaluated by the MPN method in 96-well plates: ammonium oxidizers were determined in ammonium-oxidizer broth and nitrite-oxidizers in nitriteoxidizer broth after incubation for $42 \mathrm{~d}$; denitrifying organisms (nitrate reducers and denitrifyers) were evaluated in nitrate broth after incubation for $14 \mathrm{~d}$. For total bacterial diversity (culturable and nonculturable), total soil DNA was extracted and bacterial 16S-rDNA gene fragments were amplified by PCR before analyses by DGGE. For details on the methods used, see Icoz et al [29].

No consistent statistically significant differences were observed between soils planted with $B t$ corn expressing the $\mathrm{Cry} 1 \mathrm{Ab}$ or $\mathrm{Cry} 3 \mathrm{Bb} 1$ protein or with near-isogenic non- $B t$ corn counterparts in the numbers of culturable aerobic bacteria (including actinomycetes), gram-negative bacteria, cellulose- (evaluated only in 2004) and chitin-utilizing and nitrifying and denitrifying organisms, fungi, and protozoa, determined by classical culturing techniques, and in bacterial community structure and diversity, determined by nonculture techniques (PCR-DGGE), during 4 consecutive years of corn cultivation. Some differences between $B t$ and non- $B t$ soils in the numbers of the various group of microorganisms were observed at some sampling times, but these differences were not consistent from one season to the next. Similarly, no consistent major differences were observed in the activities in soil of some representative enzymes; (i.e., arylsulfatases, acid phosphatases, alkaline phosphatases, dehydrogenases, proteases) involved in the biodegradation of plant biomass between soils with $B t$ corn or their near-isogenic non- $B t$ corn counterparts. Analysis of the data using multivariate analysis of variance (MANOVA) and split plot repeated measure ANOVA (SPRM-ANOVA) supported all of the conclusions for the main effects of treatments (i.e., $B t$ vs. non- $B t$ corn) on microbial groups and the activity of the enzymes. These results were consistent with those of Flores et al (2005), who reported that the activities of these enzymes were not consistently different in soil amended or unamended with biomass of $B t$ or non-Bt corn. Subsequent studies showed similar results in the diversity of earthworms in soil cultivated with $B t$ or isogenic non-Bt corn [190].

Plant variety had a significant, albeit transient, effect on the numbers of microorganisms and the activities of enzymes in the present study. In general, soils with varieties of $B t$ and non-Bt sweet corn (Attribute GSS-0966 and Prime Plus, respectively) had significantly higher numbers of microorganisms and higher enzyme activities than soils with $B t$ and non- $B t$ varieties of field corn (Novartis $45-\mathrm{A} 6$ and Novartis 45-T6; Pioneer 38A25 and Pioneer 38A24), as determined by ANOVA. However, these differences between varieties (sweet and field) were transient and independent of the presence of the cry gene. The numbers of microorganisms and the activity of some enzymes differed significantly with season, as determined by SPRM-ANOVA, probably as the result of differences in the water content of the soils, ambient temperatures, and stage of growth of the plants at the times of sampling. These seasonal differences were independent of the presence of the Cry proteins in the plants and, subsequently, in the soils. Although there were some statistically significant interactions between plant varieties and season, they were transient and varied during the $4 \mathrm{y}$ with no discernable trends.

DGGE analysis on the same gels of $16 \mathrm{~S}$ rDNA fragments amplified from DNA extracted from soils of $B t$ and non- $B t$ corn enabled a careful comparison of the microbial communities in these soils. The similarity of the DGGE band profiles indicated that there were no significant differences in the composition of the bacterial communities between the soils of $B t$ and non- $B t$ corn. However, there were differences in bacterial patterns between years, indicating again that the bacterial communities in these soils were influenced more by season than by the presence of the Cry proteins. These results confirmed those obtained from microbial plate counts, which also showed no consistent differences in the numbers of culturable microbes between soils with $B t$ or non- $B t$ corn but showed variations in bacterial numbers with season.

Different effects, ranging from no effects to minor and statistically significant effects, of $B t$ plants on microbial communities in soil have been reported $[29,81,126,159$ 162, 164, 166-169, 185-187]. Devare et al [191] detected no 
deleterious effects of growing $B t$ corn expressing the Cry3Bb1 protein for two consecutive seasons in the field on microbial biomass, microbial activity, or on bacterial community structure determined by terminal restriction fragment length polymorphism analysis. In a continuation of the studies of Devare et al, a 3-y field assessment of Bt corn expressing the Cry3Bb1 protein vs. near-isogenic non- $B t$ corn grown with and without the insecticide, tefluthrin, showed that neither the $B t$ corn nor the insecticide had adverse effects on microbial biomass, $\mathrm{N}$ mineralization potential, or rates of nitrification and respiration. However, effects of the rhizosphere and seasonal changes on these activities were consistently observed throughout the study, indicating that their influence on microbial biomass and activity was probably greater than any subtle effects resulting from the $B t$ corn or the insecticide [191]. Brusetti et al [160] compared the bacterial community of the rhizosphere of $B t$ and near-isogenic non- $B t$ corn using several techniques, including viable counts, community-level catabolic profiling, and PCR-based automated ribosomal intergenic spacer analysis (ARISA). Viable counts and community-level catabolic profiling did not show any differences between $B t$ and non- $B t$ corn, but ARISA showed that the community structure differed between $B t$ and non- $B t$ corn and with the age of the plants, suggesting that root exudates could select different bacterial communities. No significant effects of the Cry $1 \mathrm{Ab}$ and Cry $1 \mathrm{~F}$ proteins from $\mathrm{Bt}$ corn on bacterial and fungal phospholipid fatty acid profiles and only a few significant effects of the Cry proteins on microbial community level physiological profiles (CLPP) were reported by Blackwood and Buyer [159], and these effects were apparently the result primarily of differences in soil type.

No or minor differences in the microbial community structure of soils were observed with other Cry proteins and with products of other transgenic plants when compared with their appropriate control soils. For example, a significant, but transient, increase in the populations of culturable bacteria and fungi was found in soil microcosms amended with leaves of $B t$ cotton expressing the Cry1Ac protein [161]; minimal differences were observed in the populations of culturable aerobic bacteria and fungi in soil with transgenic $B t$ potato expressing the Cry3A protein [162]; populations of nematodes were higher in soil with transgenic tobacco expressing protease inhibitor I than with nonmodified tobacco [192]; and significantly higher levels of culturable aerobic spore-forming and cellulose-utilizing bacteria and lower enzymatic activity of dehydrogenases and alkaline phosphatases were found in soils with transgenic alfalfa expressing $\alpha$-amylase or lignin peroxidase [193]. Wu et al $[167,168]$ found that decomposing straw of $B t$ rice containing the Cry1 Ab protein was not toxic under laboratory conditions to a variety of culturable microorganisms in a flooded paddy soil. Rui et al [186] found lower numbers of culturable functional bacteria (potassium-dissolving bacteria, inorganic phosphatedissolving bacteria, and nitrogen-fixing bacteria) in the rhizosphere of $B t$ cotton than of near-isogenic non-Bt cotton only during the early and middle growth stages but not after the growing season. Shen et al [166] reported that the functional diversity of microbial communities was not different in rhizosphere soils of $B t$ and non- $B t$ cotton.
Sabharwal et al [135] reported no significant differences in the number of various groups of microorganisms and in the activities of some enzymes between rhizosphere soil of transgenic tobacco expressing HSA and of nonmodified tobacco.

By contrast, some studies have reported significant effects of $B t$ corn on microbial community structure in soil. For example, root exudates of $B t$ corn (event Bt176) significantly reduced presymbiotic hyphal growth of the arbuscular mycorrhizal fungus, Glomus mosseae (Nicolson and Gerd), compared with root exudates of another $B t$ corn hybrid (event Bt11) and non-Bt corn hybrids [187]. Castaldini et al [185] reported changes in total and metabolically-active $16 \mathrm{~S}$ rRNA fractions of culturable rhizosphere bacteria, determined by DGGE, between $B t$ corn expressing the Cry $1 \mathrm{Ab}$ protein and near-isogenic non- $B t$ corn and a significantly lower level of $G$. mosseae in roots of Bt corn. Shen et al [166] found no consistent significant differences in the enzymatic activities of urease, alkaline phosphatases, dehydrogenases, phenol oxidase, and proteases between soils of $B t$ and non- $B t$ cotton. In contrast, $\mathrm{Wu}$ et al [167, 168] reported increased activities in soil of phosphatases and dehydrogenases, as well as increased methanogenesis, after the addition of transgenic Bt-rice straw to flooded soil. Sun et al [188] also found that the addition of leaves and stems of two $B t$ cotton varieties to soil stimulated the activities in soil of urease, acid phosphomonoesterases, invertase, and cellulases, whereas the activity of arylsulfatases was inhibited.

In general, based on published data [115], the effects of transgenic $B t$ plants on microbial communities in soil seem to depend more on the species, variety, and age of the plant and on environmental factors than on the transgenes and their products. The occasional significant differences observed in the numbers of some microbial groups and in the activities of some enzymes between soils with $B t$ and non- $B t$ plants were not consistent and did not persist.

Studies were conducted to determine whether the $\mathrm{Cry} 1 \mathrm{Ab}$ protein released in root exudates and from decaying plant residues of $B t$ corn was taken up by the plants from soil in the field on which $B t$ corn had previously been grown and by carrot, as a representative root crop, in sterile hydroponic culture to which purified Cry1 Ab protein had been added [194].

\subsection{Uptake of Bt Cry Proteins by Plants in Soil and in Hydroponic Culture}

In 2005, a spectrum of vegetables was grown in a field at the Rosemount Experiment Station on which Bt corn expressing the Cry $1 \mathrm{Ab}$ protein had been grown the previous year. The experimental design was a randomized complete block with 11 plant species (15 varieties) in four blocks, each on $1 \mathrm{~m} \times 1 \mathrm{~m}$ plots for a total of 60 plots. The plants were basil (Ocimum basillicum L.), variety Genovese; beet (Beta vulgaris L.), varieties Early Wonder and Detroit Dark Red; carrot (Daucus carota L.), varieties Chantenay and Healthmaster; kale (Brassica oleracea L.), variety Dwarf Blue; lettuce (Lactuca sativa L.), variety Simpson; okra (Hibiscus esculentus L.), variety Clemson Spineless; parsnip (Pastinaca sativa L.), variety Hollow Crown; radish (Raphanus sativus L.), varieties Cherry Belle and White 
Icicle; snap bean (Phaseolus vulgaris L.), varieties Contender and Tendergreen; soybean [Glycine max (L.) Merr.], variety Edamame; and spinach (Spinacia oleracea L.), variety Bloomsdale. In 2006, vegetables were grown in seven fields at the Rosemount Experimental Station. Each field was a randomized complete block design with a total of 32 plots, which were planted with four blocks of six plant species (eight varieties), each on $1 \mathrm{~m} \mathrm{x} 1 \mathrm{~m}$ plots. The plants were basil (Genovese), carrot (Chantenay and Healthmaster), kale (Dwarf Blue), radish (White Icicle), snap bean (Contender and Tendergreen), and soybean (Edamame). Five of the seven fields had been planted to $B t$ corn expressing the Cry $1 \mathrm{Ab}$ protein in 2005, and two had not been planted to $B t$ corn since 2002. The planting history of the fields was not revealed until after completion of the study. The uptake of the $\mathrm{Cry} 1 \mathrm{Ab}$ protein by the various crops was determined with different commercial Western blot (EnviroLogix and Agdia) and ELISA (EnviroLogix, Agdia, and Abraxis) kits.

In 2005, the Cry1 Ab protein was detected by Western blot in tissues (leaves plus stems) of basil, carrot, kale, lettuce, okra, parsnip, radish, snap bean, and soybean but not in tissues of beet and spinach, and was estimated by ELISA to be $0.05 \pm 0.003 \mathrm{ng} / \mathrm{g}$ of fresh plant tissue in basil, $0.02 \pm 0.014 \mathrm{ng} / \mathrm{g}$ in okra, and $0.34 \pm 0.176 \mathrm{ng} / \mathrm{g}$ in snap bean. However, the protein was not detected by ELISA in carrot, kale, lettuce, parsnip, radish, and soybean or, by Western blot, in the soils on which the vegetables had been grown. In 2006, the Cry1Ab protein was detected by Western blot in tissues of basil, carrot, kale, radish, snap bean, and soybean from soils on which $B t$ corn had been grown the previous year and was estimated by ELISA to be $0.02 \pm 0.014 \mathrm{ng} / \mathrm{g}$ of fresh plant tissue in basil, $0.19 \pm 0.060 \mathrm{ng} / \mathrm{g}$ in carrot, $0.05 \pm 0.018 \mathrm{ng} / \mathrm{g}$ in kale, $0.04 \pm 0.022 \mathrm{ng} / \mathrm{g}$ in radish, $0.53 \pm 0.170 \mathrm{ng} / \mathrm{g}$ in snap bean, and $0.15 \pm 0.071 \mathrm{ng} / \mathrm{g}$ in soybean. The Cry1 Ab protein was also detected by Western blot in tissues of basil, carrot, kale, radish, and snap bean but not of soybean grown in soil on which $B t$ corn had not been grown since 2002; the concentration was estimated by ELISA to be $0.03 \pm 0.021 \mathrm{ng} / \mathrm{g}$ in basil, $0.02 \pm 0.008 \mathrm{ng} / \mathrm{g}$ in carrot, $0.04 \pm 0.017 \mathrm{ng} / \mathrm{g}$ in kale, $0.02 \pm 0.012 \mathrm{ng} / \mathrm{g}$ in radish, $0.05 \pm 0.004 \mathrm{ng} / \mathrm{g}$ in snap bean, and $0.09 \pm 0.015 \mathrm{ng} / \mathrm{g}$ in soybean. The protein was detected by Western blot in 2006 in most soils on which $B t$ corn had or had not been grown since 2002 [194].

The Cry $1 \mathrm{Ab}$ protein was also detected by Western blot in leaves plus stems and in roots of carrot after 56 days of growth in sterile hydroponic culture to which purified Cry $1 \mathrm{Ab}$ protein had been added and was estimated by ELISA to be $0.08 \pm 0.021$ and $0.60 \pm 0.148 \mathrm{ng} / \mathrm{g}$ of fresh leaves plus stems and roots, respectively. No Cry $1 \mathrm{Ab}$ protein was detected in the tissues of carrot grown in hydroponic culture to which no Cry $1 \mathrm{Ab}$ protein had been added.

Some of the results of this study [194] in which the Cry1 Ab protein was apparently not taken up by plants from soils on which $B t$ corn had been previously grown, were in agreement with results of Saxena and Stotzky [82, 195], who reported no uptake of the Cry1 Ab protein, using the Western blot kit from EnviroLogix, by: (1) non-Bt corn, carrot, radish, and turnip grown in soil, in a plant-growth room, on which $B t$ corn had been grown or which had been amended with purified Cry1 Ab protein or ground biomass of $B t$ corn; or (2) by non-Bt corn grown in sterile hydroponic culture in which $B t$ corn had previously been grown. However, some other results of this study were not in agreement with those of Saxena and Stotzky [82, 195], as the Cry1Ab protein was detected in the tissues of various plants grown on soil previously planted to $B t$ corn by the Western blot kit from Agdia and by the ELISA kits from Agdia and Abraxis. The reasons for the differences in the results with kits from different manufacturers are not known. The differences may have been the result of the relative accuracy and sensitivity of the kits from different manufacturers; of the possibility of false positives or negatives in the assays, despite the large number of replicate analyses of each field-grown plant variety (12 Western blots and eight ELISAs per plant variety); or of differences in the chemical composition of the extracts from different plant species, and perhaps some components in the extracts, other than the Cry1 Ab protein, may have interacted with components of the kits to give false positive results. However, the latter possibility is remote, as numerous negative results were obtained with extracts from the same plants grown in soil that had not recently been planted with Bt corn. Moreover, in 2006, the Cry1Ab protein was detected in the soils on which the plants were grown, whereas it was not detected in the same soils in 2005. In addition, the protein was also detected in most of the soils on which $B t$ corn had not been planted since 2002. More detailed studies with additional techniques are obviously needed to confirm the uptake of Cry proteins from soil by plants subsequently planted after $B t$ crop.

Although this study indicated that some plant species grown in soils on which $B t$ corn had been grown take up the Cry $1 \mathrm{Ab}$ protein, albeit in small amounts, more detailed studies with different methods and techniques are obviously needed to confirm this uptake [194]. If confirmed, the risks to the environment of such uptake will need to be evaluated. Furthermore, although HGT among microorganisms has been demonstrated in soil microcosms [70, 74, 76, 78, 86, $90,94,95,97,99,100,106,112,118,196-201]$, and the $c r y 1 A b$ gene has been shown to be transported in soil and waters, there is scant evidence for the uptake of cry genes by plants and other organisms from the environment [202]. Donnarumma et al studied the possible transfer of genes from Btk to the indigenous Bacillus spp. in soil from the soil samples collected 5 years after treatment of stands of cork oak in Sardinia with a commercial insecticide containing Btk. PCR amplification of DNA purified from the two isolates identified as Bacillus mycoides with the primers for identification of cry genes of Btk showed the presence of 238-bp fragment of the $c r y 1 A b 9$ gene indicating the presence of this fragment in DNA of the two isolates. No Btk or Cry protein was detected in adjacent unsprayed soils indicating that $B t k$ is not normally present in these soils. Hybridization with probes for IS231 and the crylAb9 gene suggested that the inverted repeated sequence IS231 was probably involved in the transfer of 238-bp fragment from Btk to B. mycoides. These results indicate the possible occurrence of gene transfer between introduced Btk and indigenous Bacillus spp. in soil under field conditions. The uptake of cry genes could result in the expression of Cry proteins in plants, more studies on the uptake of cry genes by different plant species in soil in situ are also necessary. Such HGT of cry genes might also explain the discrepancies between the detection of 
the Cry1 $\mathrm{Ab}$ protein in plants grown in soils either previously planted or not planted with $B t$ corn.

\section{RISKS AND BENEFITS OF "MOLECULAR PHARMING"}

"Molecular pharming" [79, 135, 203-215] utilizes transgenic plants and animals to produce pharmaceuticals for use in human beings, chemicals for industrial purposes, and other compounds that are not intended to enter food and feed supplies [216]. The transgenic organisms have been genetically altered by the insertion of foreign genes, which, when expressed, enable the organisms to synthesize pharmaceuticals and other compounds in their tissues. These compounds have numerous therapeutic purposes, such as treatment of cystic fibrosis, hemophilia, osteoporosis, arthritis, malaria, and HIV. An overview of some aspects of molecular pharming is depicted in Table 1. Some vaccines produced in plants are edible (oral immunotherapy), which may be important in delivery and prevention of spoilage, especially in areas where refrigeration is limited [135, 205, 211, 217-225].

Although there are some disadvantages in molecular pharming (e.g., the reproducibility of activity and production, which are dependent on environmental conditions, such as climate and location; possible effects on the population structure of insects and other animals that feed on plants, as well as on the soil microbiota; allergens, especially in plants that contain fucose and xylose residues on glycoproteins; possibility of horizontal gene transfer of the novel genes in transgenic plants to soil microbes; transfer of the novel genes to sexually-compatible plants, including weeds; commingling of seeds and other parts of transgenic plants with those of food and feed crops; recurrence in crops with multiyear seed dormancy, such as alfalfa and canola, where fallowing or replanting with a nontransgenic crop

\section{Table 1. Some ASPEcts of Molecular "Pharming", Modified, with Permission, from Stotzky and Saxena [79]}

- Molecular "pharming" utilizes transgenic plants and animals to produce pharmaceuticals and other drug molecules for use primarily in human beings (e.g., vaccines, hormones, antibodies, blood substitutes, antigens, enzymes, toxins).

- These pharmaceutical products are seldom found in natural habitats; hence, they are environmental "xenobiotics".

- Their persistence in and effects on the environment have not been studied adequately; hence, potential hazards are not known.

- In contrast to the products of pesticidal transgenic plants, the targets of these biomolecules are human beings and other "higher level" eukaryotes rather than insects, nematodes, and protozoa.

- The products of the foreign genes are usually expressed in leaves, stems, roots, and pollen of transgenic plants and in milk, blood, urine, sperm, eggs, and other tissues of transgenic animals.

- Many of the products have therapeutic purposes, such as treatment of cystic fibrosis, hemophilia, osteoporosis, arthritis, malaria, and HIV.

- Some vaccines produced in plants are edible (oral immunotherapy), which may be important in delivery and in prevention of spoilage, especially in developing countries where refrigeration is limited.

- Production of these biomolecules in transgenic plants and animals is presumably more economical than production by classical chemical and microbiological methods.

- Animals in "biofactory" farms are also exposed to toxic chemicals, artificial hormones, antibiotics, tranquilizers, appetite stimulants, insecticides, herbicides, etc.

- These compounds can be passed to human beings in meat and to the environment in urine, feces, and carcasses.

- Expressed proteins from transgenic plants will be released to the environment in root exudates, pollen, and biomass after harvest of crops.

- These biomolecules will probably persist and accumulate in the environment, as the result of their binding on surface-active particles (e.g., clays, humic substances), which reduces their biodegradation, as has been observed with other proteins, DNA, viruses, etc.

- Persistence and potential effects of these biomolecules on indigenous organisms in recipient natural habitats (e.g., on microbial populations and processes in soil necessary for biogeochemical cycling and crop production) must be established before the increased release of such transgenic plants and animals.

- Studies of bioactive compounds released by transgenic plants and animals will also provide information about the persistence and potential effects of pharmaceuticals and other biomolecules that reach soil and waters from numerous other sources.

- A broad spectrum of pharmaceuticals has already been detected in sewage sludge and effluent, surface and ground waters (even in tap water), and soils of feedlots and under landfills: e.g., aspirin; caffeine; nicotine; estradiol; anti-inflammatory drugs, such as diclofenac; analgesics, such as phenazone; anticonvulsive drugs, such as carbamazepine and phenosuximide; cholesterol-lowering drugs, such as clofibric acid; anticancer agents; psychiatric drugs, such as pentobarbital and meprobamate; antibiotics used in both animal production and human health; numerous compounds used in cosmetics.

- Most of these compounds are probably released in minute amounts; however, they could accumulate and persist when bound on surface-active particles.

- These bound compounds can be transported through soil and water by "colloid-facilitated transport". 
Table 2. Information Needed About the Fate and Effects in Natural Habitats, Especially in Soil, of Biomolecules Produced by Transgenic Plants and Animals, Modified, with Permission, from Stotzky and Saxena [79]

\begin{tabular}{|ll|}
\hline - & Do these biomolecules bind on soil, especially on surface-active components? \\
\hline - & Influence of the physicochemical and biological characteristics of soil on binding. \\
\hline - & Does binding affect persistence (e.g., - resistance to biodegradation) and bioactivity? \\
\hline - & Effects of free and bound biomolecules on microbe-mediated processes and microbial community structure. \\
\hline - & Release, persistence, and ecological effects of biomolecules released in root exudates and biomass. \\
\hline - & Uptake of released biomolecules by plants and other organisms; potential effects on food webs. \\
\hline - & Development of rapid and quantitative methods to follow the environmental fate of biomolecules. \\
\hline - & Physicochemical properties of complexes between biomolecules and surface-active particles. \\
\hline - & Mechanisms involved in above phenomena. \\
\hline
\end{tabular}

does not eliminate the possibility of contamination with volunteers of the original transgenic crop), many of these potential problems can be mitigated by physical isolation and containment (e.g., in greenhouses and underground mines) of the transgenic crop, differential planting seasons, use of male-sterile plants, use of transplastomic plants (however, there is no glycosylation in chloroplasts), and use of inducible promoters. Nevertheless, many of these mitigation procedures are expensive, which could negate some of the advantages of using transgenic plants for the production of pharmaceuticals and other chemicals [79].

Among the difficulties in assessing the risk of "pharming" is what to look for with respect to their potential environmental effects, considering the current inability to predict how potential ecological impacts will be expressed.
At what environmental level should impacts be sought (micro- vs. macroecology)? What techniques are most appropriate to detect impacts? Perhaps most important, how to interpret the results (statistical vs. ecological significance)? These are obviously open-ended questions with a potentially unlimited number of answers [226]. To determine the environmental effects of the products of "pharms", some studies that appear to be needed are suggested in Table 2. If these and other studies are not conducted before the large-scale release of "pharm" plants, the situation depicted in Fig. (1) may become a reality. The release to the environment, especially to soil and potentially to waters of the pharmaceutical and industrial products of transgenic plant and animal "pharms" could pose a hazard to the environment. In contrast to the products of most

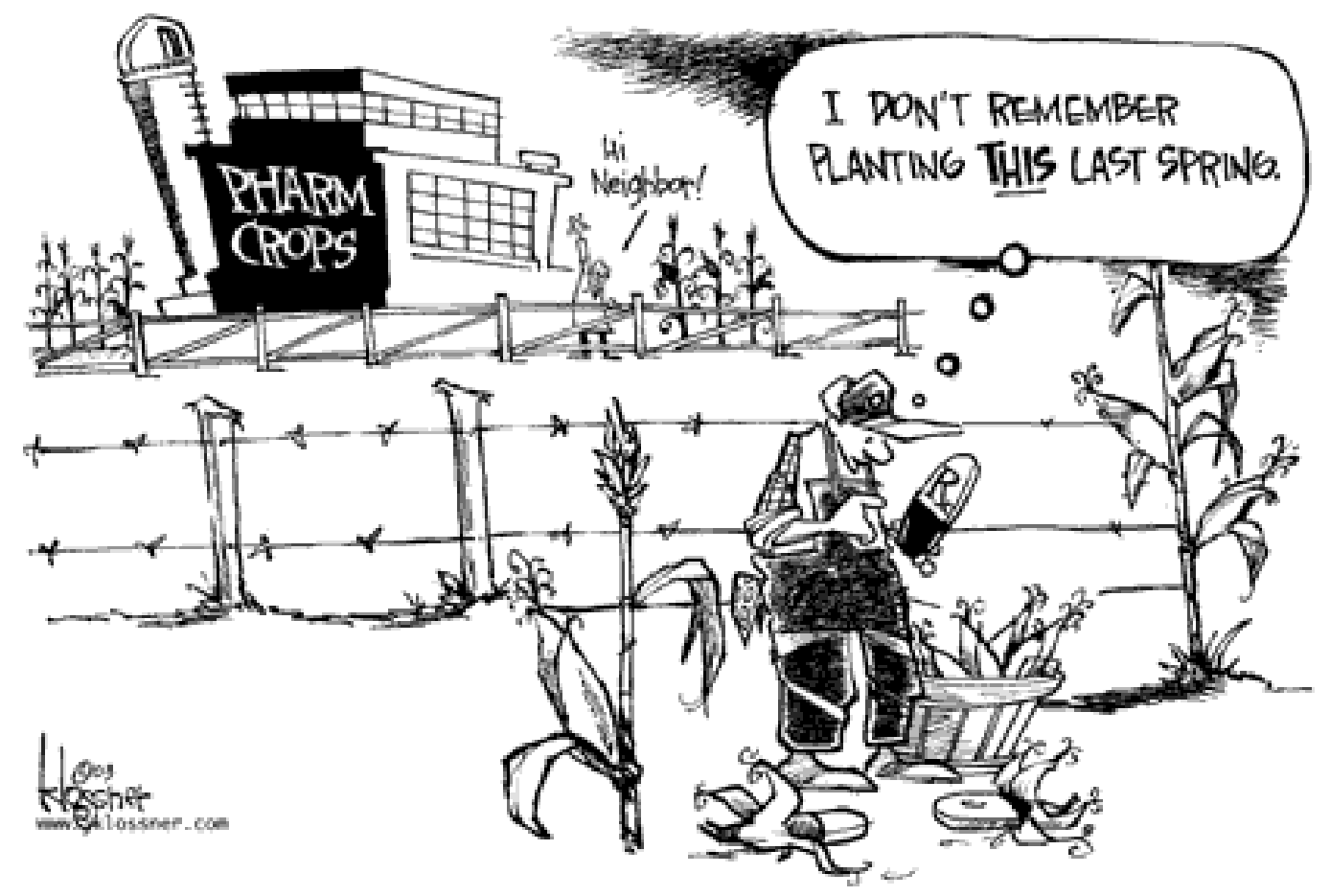

Fig. (1). Realistic paradigm of "Pharm" crops factories, with kind permission of John Klossner,

Copyright 2003 John Klossner, www.jklossner.com). 
transgenic plants currently available commercially (e.g., the insecticidal proteins from subspecies of $B t$ ) that are targeted primarily to insects and other pests, these "pharms" are being genetically engineered to express products for use primarily in human beings. Consequently, these products constitute a class of compounds that is seldom found in natural habitats and that is targeted primarily to "higher level" eukaryotes. Hence, they are xenobiotics with respect to the environment, and their persistence in and effects on the environment have not been adequately studied.

\section{CONCLUDING STATEMENT}

Although the potential for biotechnology to provide advances in human health and agricultural production appears to be unlimited, the occurrence of unanticipated problems must be considered and studied before they arise and before the large-scale release of transgenic organisms is sanctioned by regulatory agencies. The release of bioactive molecules that are not normally present in soil and other natural habitats could negatively affect, for e.g., microbial processes and populations that are essential for biogeochemical cycling and crop production. This technology is so new and powerful that it is not possible to predict accurately the ecological and environmental effects of the release of such genetically engineered organisms and their products to the environment. Much research, money, and time have been invested in this technology, which could end massive human hunger and suffering, and neither producers nor consumers can afford to "give up" on this technology and its potential benefits. However, it would be unethical and dangerous to disseminate indiscriminately new genetic material and its products in the environment without thoroughly investigating the risks. Consequently, sober risk assessments on a case-by-case basis must be made before major releases of such transgenic organisms. Failure to investigate these risks fully could cause extensive, and perhaps irreversible, environmental damage which could be dangerous to present and future generations.

\section{ACKNOWLEDGEMENTS}

Preparation of this review was supported, in part, by grants from the US Department of Agriculture (USDA), the New York University Research Challenge Fund (NYURCF) and the NYU College of Dentistry Faculty Funds. The opinions expressed herein are not necessarily those of the USDA, NYURCF or Faculty Funds.

\section{REFERENCES}

[1] Bravo A, Hendrickx K, Jansens S, Peferoen M. Immunocytochemical analysis of specific binding of Bacillus thuringiensis insecticidal crystal proteins to lepidopteran and coleopteran midgut membranes. J Invertebr Pathol 1992; 60: 24753 .

[2] Denolf P, Jansens S, Peferoen M, Degheele D, Van Rie J. Two different Bacillus thuringiensis $\delta$-endotoxin receptors in the midgut brush border membrane of the European Corn Borer, Ostrinia nubilalis (Hübner) (Lepidoptera: Pyralidae). Appl Environ Microbiol 1993; 59: 1828-37.

[3] Höfte H, Whiteley HR. Insecticidal crystal proteins of Bacillus thuringiensis. Microbiol Rev 1989; 53: 242-55.

[4] Adang MJ. In: Maramorosch K, Ed. Bacillus thuringiensis insecticidal crystal proteins: genestructure, action, and utilization. Biotechnology for Biological Control of Pests and Vectors. CRC Press, Boston, MA, USA 1991; pp. 3-24.
[5] Wolfersberger MG. The toxicity of two Bacillus thuringiensis $\delta$ endotoxins to gypsy moth larvae is inversely related to the affinity of binding sites on midgut brush border membranes for the toxins. Experientia 1990; 46: 475-7.

[6] Van Rie J, Jansens S, Hoëfte H, Degheele D, Van Mallaert H. Receptors on the brush border membrane of the insect midgut as determinants of the specificity of Bacillus thuringiensis $\delta$ endotoxins. Appl Environ Microbiol 1990a; 56: 1378-85.

[7] Garczynski SF, Crim JW, Adang MJ. Identification of putative insect brush border membrane-binding molecules specific to Bacillus thuringiensis $\delta$-endotoxin by protein blot analysis. Appl Environ Microbiol 1991; 57: 2816-20.

[8] Crickmore N, Zeigler DR, Feitelson J, et al. Revision of the nomenclature for the Bacillus thuringiensis pesticidal crystal proteins. Microbiol Mol Biol Rev 1998; 62: 807-13.

[9] Federici BA. In: Atherton KT, Ed. Case study: $B t$ crops, a novel mode of insect control. Genetically Modified Crops: Assessing Safety. Taylor \& Francis Inc., New York, NY 2002; pp. 164-200.

[10] Lee L, Saxena D, Stotzky G. Activity of free and clay-bound insecticidal proteins from Bacillus thuringiensis subsp. israelensis against the mosquito Culex pipiens. Appl Environ Microbiol 2003; 69: 4111-5.

[11] Schnepf E, Crickmore N, Van Rie J, et al. Bacillus thuringiensis and its pesticidal crystal proteins. Microbiol Mol Biol Rev 1998; 62: 775-806.

[12] Stotzky G. In: Letourneau DK, Burrows BE, Eds. Release, persistence and biological activity in soil of insecticidal proteins from Bacillus thurengiensis. Genetically Engineered Organisms: Assessing Environmental and Health Effects. CRC Press: Boca Raton 2002; pp. 187-222.

[13] Ito A, Sasaguri Y, Kitada S, et al. A Bacillus thuringiensis crystal protein with selective cytocidal action to human cells. J Biol Chem 2004; 279: 21282-6.

[14] Katayama H, Yokota H, Akao T, et al. Parasporin-1, a novel cytotoxic protein to human cells from non-insecticidal parasporal inclusions of Bacillus thuringiensis. J Biochem 2005; 137: 17-25.

[15] Lee DW, Akao T, Yamashita S, et al. Noninsecticidal parasporal proteins of a Bacillus thuringiensis serovar shandongiensis isolate exhibit a preferential cytotoxicity against human leukemic $\mathrm{T}$ cells. Biochem Biophys Res Commun 2000; 272: 218-23.

[16] Lee DW, Katayama H, Akao T, et al. A 28-kDa protein of the Bacillus thuringiensis serovar shandongiensis isolate 89-T-34-22 induces a human leukemic cell-specific cytotoxicity. Biochim Biophys Acta 2001; 1547: 57-63.

[17] Mizuki E, Ohba M, Akao T, Yamashita S, Saitoh H, Park YS. Unique activity associated with non-insecticidal Bacillus thuringiensis parasporal inclusions: in vitro cell-killing action on human cancer cells. J Appl Microbiol 1999; 86: 477-86.

[18] Mizuki E, Park YS, Saitoh H, et al. Parasporin, a human leukemic cell-recognizing parasporal protein of Bacillus thuringiensis. Clin Diagn Lab Immunol 2000; 7: 625-34.

[19] Okumura S, Akao T, Higuchi K, et al. Bacillus thuringiensis serovar shandongiensis strain 89-T-34-22 produces multiple cytotoxic proteins with similar molecular masses against human cancer cells. Lett Appl Microbiol 2004; 39: 89-92.

[20] Prasad SSSV, Shethna YI. Purification, crystallization and partial characterization of the anti-tumor and insecticidal protein subunit from the $\delta$-endotoxin of Bacillus thuringiensis var. thuringiensis. Biochim Biophys Acta 1974; 363: 558-66.

[21] Seki T, Nagamatsu Y, Mizuki E, et al. Injuring reaction of $\delta$ endotoxin upon sarcoma 180 ascites cells and silkworm midgut cells in vitro. Microbiology 1978; 33: 19-24.

[22] Beegle CC, Yamamoto T. History of Bacillus thuringiensis Berliner research and development. Can Entomol 1992; 124: 587616.

[23] Entwistle PF, Corey JS, Bailey MJ, Higgs S, Eds. Bacillus thuringiensis, an Environmental Biopesticide: Theory and Practice. John Wiley \& Sons: Chichester, UK 1993.

[24] Feitelson JS, Payne SJ, Kim L. Bacillus thuringiensis: insects and beyond. BioTechnology 1992; 10: 271-5

[25] Feitelson JS. In: Kim L, Ed. The Bacillus thuringiensis family tree. Advanced Engineered Pesticides. Marcel Dekker, New York, NY 1993; 63-71.

[26] Saxena D, Stewart CN, Altosaar I, Shu Q, Stotzky G. Larvicidal Cry proteins from Bacillus thuringiensis are released in root 
exudates of transgenic $B$. thuringiensis corn, potato, and rice but not of B. thuringiensis canola, cotton, and tobacco. Plant Physiol Biochem 2004; 42: 383-7.

[27] Losey JE, Rayor LS, Carter ME. Transgenic pollen harms monarch larvae. Nature 1999, 399: 214

[28] Obrycki JJ, Losey JE, Taylor OR, Jesse LCH. Transgenic insecticidal corn: beyond insecticidal toxicity to ecological complexity. Bioscience 2001; 51:353-61.

[29] Icoz I, Saxena D, Andow DA, Zwahlen C, Stotzky G. Microbial populations and enzyme activities in soil in situ under transgenic corn expressing Cry proteins from Bacillus thuringiensis. J Environ Qual 2008; 37: 647-62.

[30] Saxena D, Flores S, Stotzky G. Insecticidal toxin in root exudates from $B t$ corn. Nature 1999; 402:480.

[31] Saxena D, Stotzky G. Insecticidal toxin from Bacillus thuringiensis is released from roots of transgenic Bt corn in vitro and in situ. FEMS Microbiol Ecol 2000; 33: 35-9.

[32] Addison JA. Persistence and nontarget effects of Bacillus thuringiensis in soil: a review. Can J Forest Res 1993; 23: 2329-42.

[33] Flexner JL, Lighthard B, Croft BA. The effects of microbial pesticides on non-target, beneficial, arthropods. Agricult Ecosys Environ 1986; 16: 203-54.

[34] Goldburg RJ, Tjaden G. Are B.T.K. plants really safe to eat? Bio Technology 1990; 8: 1011-5.

[35] Johnson KS, Scriber JM, Nitao JK, Smitley DR. Toxicity of Bacillus thuringiensis var. kurstaki to three nontarget Lepidoptera in field studies. Environ Entomol 1995; 24: 288-97.

[36] Petras SF, Casida LE. Survival of Bacillus thuringiensis spores in soil. Appl Environ Microbiol 1985; 50: 1496-501.

[37] Saleh SM, Harris RF, Allen ON. Recovery of Bacillus thuringiensis var. thuringiensis from field soils. J Invertebr Pathol 1970; 15: 55-9.

[38] West AW. Fate of the insecticidal, proteinaceous, parasporal crystal of Bacillus thuringiensis in soil. Soil Biol Biochem 1984; 16: 351-60

[39] West AW, Burges HD, Wyborn CH. Effect of incubation in natural and autoclaved soil upon potency and viability of Bacillus thuringiensis. J Invert Pathol 1984a; 44: 121-7.

[40] West AW, Burges HD, White RJ, Wyborn CH. Persistence of Bacillus thuringiensis parasporal crystal insecticidal activity in soil. J Invert Pathol 1984b; 44: 128-33.

[41] West AW, Burges HD, Dixon TJ, Wyborn CH. Survival of Bacillus thuringiensis and Bacillus cereus spore inocula in soil, effects of $\mathrm{pH}$, moisture, nutrient availability and indigenous microorganisms. Soil Biol Biochem 1985; 17: 657-65.

[42] West AW, Burges HD. Persistence of Bacillus thuringiensis and Bacillus cereus in soil supplemented with grass or manure. Plant Soil 1985; 83: 389-98.

[43] Griego VM, Spence KD. Inactivation of Bacillus thuringiensis spores by ultraviolet and visible light. Appl Environ Microbiol 1978; 35: 906-10.

[44] Ignoffo CM, Garcia C. UV-photoinactivation of cells and spores of Bacillus thuringiensis and effects of peroxide on inactivation. Environ Entomol 1978; 7: 270-2.

[45] Vettori C, Paffetti D, Saxena D, Stotzky G, Giannini R. Persistence of toxins and cells of Bacillus thuringiensis subsp. kurstaki introduced in sprays to Sardinia soils. Soil Biol Biochem 2003; 35: 1635-42.

[46] Hilbeck A, Baumgartner M, Fried PM, Bigler F. Effects of transgenic Bt corn-fed prey on immature development of Chrysoperla carnea (Neuroptera: Chrysopidae). Environ Entomol 1998a; 27: 480-7.

[47] Hilbeck A, Moar W, Pusztai-Carey M, Filipini A, Bigler F. Toxicity of Bacillus thuringiensis Cry1 Ab toxin to the predator Chrysoperla carnea (Neuroptera: Chrysopidae). Environ Entomol 1998b; 27: 1255-63.

[48] Hilbeck A, Moar WJ, Pusztai-Carey M, Filippini A and Bigler F. Prey-mediated effects of Cry1 $\mathrm{Ab}$ toxin and protoxin and Cry2A protoxin on the predator Chrysoperla carnea. Entomol Exp Appl 1999; 91: 305-16.

[49] James RR, Miller JC, Lighthart B. Bacillus thuringiensis var. kurstaki affects a beneficial insect, the Cinnabar moth (Lepidoptera: Arctiidae). J Econ Entomol 1993; 86: 334-9.

[50] McGaughey WH, Whalon ME. Managing insect resistance to Bacillus thuringiensis toxins. Science 1992; 258: 1451-5.
[51] Tabashnik BE. Evolution of resistance to Bacillus thuringiensis. Annu Rev Entomol 1994; 39: 47-79.

[52] Van Rie J, McGaughey WH, Johnson DE, Barnett BD, Van Mellaert H. Mechanism of insect resistance to the microbial insecticide of Bacillus thuringiensis. Science 1990; 247: 72-4.

[53] Bauer LS. Resistance: a threat to the insecticidal crystal proteins of Bacillus thuringiensis. Fla Entomol 1995; 78: 414-43.

[54] Ferre J, Escriche B, Bel Y, Van Rie J. Biochemistry and genetics of insect resistance to Bacillus thuringiensis insecticidal crystal proteins. FEMS Microbiol Lett 1995; 132: 1-7.

[55] Tabashnik BE, Liu YB, Malvar T, et al. Global variation in the genetic and biochemical basis of diamond back moth resistance to Bacillus thuringiensis. Proc Natl Acad Sci U S A 1997; 94:127805 .

[56] Saxena D, Stotzky G. Fate and effects in soil of insecticidal toxins from Bacillus thuringiensis in transgenic plants. In: Collection of Biosafety Reviews, International Centre for Genetic Engineering and Biotechnology, Trieste 2003; pp. 7-83.

[57] Stotzky G. Persistence and biological activity in soil of insecticidal proteins from Bacillus thuringiensis and of bacterial DNA bound on clays and humic acids. J Environ Qual 2000; 29: 691-705.

[58] Stotzky G. In: Huang PM, Schnitzer M, Eds. Influence of soil mineral colloids on metabolic processes, growth, adhesion, and ecology of microbes and viruses. Interactions of soil minerals with natural organics and microbes. Soil Science Society of America, Madison 1986; pp. 305-428.

[59] Fiorito TM, Icoz I, Stotzky G. Adsorption and binding of the transgenic plant proteins, human serum albumin, $\beta$-glucuronidase, and $\mathrm{Cry} 3 \mathrm{Bb} 1$, on montmorillonite and kaolinite: microbial utilization and enzymatic activity of free and clay-bound proteins. Appl Clay Sci 2008; 39: 142-50

[60] Koskella J, Stotzky G. Microbial utilization of free and clay-bound insecticidal toxins from Bacillus thuringiensis and their retention of insecticidal activity after incubation with microbes. Appl Environ Microbiol 1997; 63: 3561-8.

[61] Tapp H, Calamai L, Stotzky G. Adsorption and binding of the insecticidal proteins from Bacillus thuringiensis subsp. kurstaki and subsp. tenebrionis on clay minerals. Soil Biol Biochem 1994; 26: 663-79.

[62] Tapp H, Stotzky G. Persistence of the insecticidal toxins from Bacillus thuringiensis subsp. kurstaki in soil. Soil Biol Biochem 1998; 30: 471-6.

[63] Tapp H, Stotzky G. Dot Blot Enzyme-linked immunosorbent assay for monitoring the fate of insecticidal toxins from Bacillus thuringiensis in soil. Appl Environ Microbiol 1995a; 61: 602-9.

[64] Tapp H, Stotzky G. Insecticidal activity of the toxins from Bacillus thuringiensis subspecies kurstaki and tenebrionis adsorbed and bound on pure and soil clays. Appl Environ Microbiol 1995b; 61: 1786-90.

[65] Tapp H, Stotzky G. Monitoring the insecticidal toxins from Bacillus thuringiensis in soil with flow cytometry. Can J Microbiol 1997; 43: 1074-8.

[66] Venkateswerlu G, Stotzky, G. Binding of the protoxin and toxin protein of Bacillus thuringiensis subsp. kurstaki on clay minerals. Curr Microbiol 1992; 25: 1-9.

[67] Venkateswerlu G, Stotzky G. Simple method for the isolation of the antilepidopteran toxin from Bacillus thuringiensis subsp. kurstaki. Biotechnol Appl Biochem 1990; 12: 245-51.

[68] Koskella J, Stotzky G. Resistance of the toxins from Bacillus thuringiensis to biodegradation when bound on clay minerals. In: Abstracts of the 94th General Meeting of the American Society for Microbiology 1994: Session 72:Q71: 1994; American Society for Microbiology, Washington, D.C, 1994; p. 400.

[69] Stotzky G. In: Laskin AI, Lechevalier H, Eds. Activity, ecology, and population dynamics of microorganisms in soil. Microbial Ecology. CRC Press: Cleveland 1974; pp. 57-135.

[70] Crecchio C, Stotzky G. Insecticidal activity and biodegradation of the toxin from Bacillus thuringiensis subsp. kurstaki bound to humic acids from soil. Soil Biol Biochem 1998; 30: 463-70.

[71] Schnell DJ, Pfannenstiel MA, Nickerson KW. Bioassay of solubilized Bacillus thuringiensis var. israelensis crystals by attachment to latex beads. Science 1984; 223: 1191-3.

[72] Crecchio C, Stotzky G. Biodegradation and insecticidal activity of the toxin from Bacillus thuringiensis subsp. kurstaki bound on 
complexes of montmorillonite-humic acids-Al hydroxypolymers. Soil Biol Biochem 2001; 35: 573-81.

[73] Convents D, Cherlet M, Van Damme J, Lasters I, Lauwereys M. Two structural domains as a general fold of the toxic fragment of the Bacillus thuringiensis $\delta$-endotoxins. Eur J Biochem 1991; 195: 631-5.

[74] Gallori E, Bazzicalupo M, Dal Canto L, et al. Transformation of Bacillus subtilis by DNA bound on clay in non-sterile soil. FEMS Microbiol Ecol 1994; 15: 119-26.

[75] Khanna M, Stotzky G. Transformation of Bacillus subtilis by DNA bound on montmorillonite and effect of DNase on the transforming ability of bound DNA. Appl Environ Microbiol 1992; 58: 1930-9.

[76] Stotzky G. In: Levy SB, Miller RV, Eds. Gene transfer among bacteria in soil. Gene Transfer in the Environment. McGraw-Hill, NY 1989; pp. 165-222.

[77] Ghosal D, You IS, Chatterjee DK, Chakrabarty AM. Microbial degradation of halogenated compounds. Science 1985; 228: 13542.

[78] Pontiroli A, Simonet P, Frostegard A, Vogel TM, Monier JM. Fate of transgenic plant DNA in the environment. Environ Biosafety Res 2007; 6: 15-35.

[79] Stotzky G, Saxena D. In: Halley GT, Fridian YT, Eds. Is molecular "pharming" a potential hazard to the environment? Environmental impact assessments. Nova Science Publishers, Inc., New York, NY 2009; pp. 77-86.

[80] Muchaonyerwa P, Waladde S, Nyamugafata P, Mpepereki S, Ristori GG. Persistence and impact on microorganisms of Bacillus thuringiensis proteins in some Zimbabwean soils. Plant Soil Biol Biochem 2004; 266: 41-6.

[81] Saxena D, Stotzky, G. Bacillus thuringiensis (Bt) toxin released from root exudates and biomass of $B t$ corn has no apparent effect on earthworms, nematodes, protozoa, bacteria, and fungi in soil. Soil Biol Biochem 2001b; 33: 1225-30.

[82] Saxena D, Flores S, Stotzky G. Vertical movement in soil of insecticidal Cry1 Ab protein from Bacillus thuringiensis. Soil Biol Biochem 2002a; 34: 111-20.

[83] Saxena D, Flores S, Stotzky G. Bt toxin is released in root exudates from 12 transgenic corn hybrids representing three transformation events. Soil Biol Biochem 2002b; 34: 133-7.

[84] Stotzky G. Persistence and biological activity in soil of the insecticidal proteins from Bacillus thuringiensis, especially from transgenic plants. Plant Soil 2004; 266: 77-89.

[85] Zwahlen C, Hilbeck A, Gugerli P, Nentwig W. Degradation of the $\mathrm{Cry} 1 \mathrm{Ab}$ protein within transgenic Bacillus thuringiensis corn tissue in the field. Mol Ecol 2003; 12: 765-75.

[86] Ceccherini MT, Pote J, Kay E, et al. Degradation and transformability of DNA from transgenic leaves. Appl Environ Microbiol Mol Biol Rev 2003; 69: 673-8.

[87] Gebhard F, Smalla K. Monitoring field releases of genetically modified sugar beets for persistence of transgenic plant DNA and horizontal gene transfer. FEMS Microbiol Ecol 1999; 28: 261-72.

[88] Paget E, Lebrun M, Freyssinet G, Simonet P. The fate of recombinant plant DNA in soil. Eur J Soil Biol 1998; 34: 81-8.

[89] Widmer F, Seidler RJ, Donegan KK, Reed GL. Quantification of transgenic plant marker gene persistence in the field. Mol Ecol 1997; 6: 1-7.

[90] Monier JM, Bernillon D, Kay E, et al. Detection of potential transgenic plant DNA recipients among soil bacteria. Environ Biosafety Res 2007; 6: 71-83.

[91] Nielsen KM, Johnsen PJ, Bensasson D, Daffonchio D. Release and persistence of extracellular DNA in the environment. Environ Biosafety Res 2007; 6: 37-53.

[92] Redfield RJ. Evolution of bacterial transformation: is sex with dead cells ever better than no sex at all? Genetics 1988; 119: 213-21.

[93] Widmer F, Seidler RJ, Watrud LS. Sensitive detection of transgenic plant marker gene persistence in soil microcosms. Mol Ecol 1996; 5: 603-13.

[94] Yin X, Stotzky G. Gene transfer among bacteria in natural environments. Adv Appl Microbiol 1997; 45: 153-212.

[95] Lorenz MG, Wackernagel W. Bacterial gene transfer by natural genetic transformation in the environment. Microbiol Rev 1994; 58: 563-602.

[96] Neilson JW, Josephson KL, Pepper IL, Arnold RB, Di Giovanni GD, Sinclair NA. Frequency of horizontal gene transfer of a large catabolic plasmid (pJP4) in soil. Appl Environ Microbiol 1994; 60: 4053-8.

[97] Bertolla F, Simonet P. Horizontal gene transfer in the environment: natural transformation as a putative process for gene transfers between transgenic plants and microorganisms. Res Microbiol Mol Biol Rev 1999; 150: 375-84.

[98] Fall S, Mercier A, Bertolla F, et al. Horizontal gene transfer regulation in bacteria as a "spandrel" of DNA repair mechanisms. PLoS One 2007; 2: e1055.

[99] Heüer H, Smalla K. Horizontal gene transfer between bacteria. Environ Biosaf Res 2007, 6: 3-13.

[100] Miller RV. Scambio di geni tra batteri in natura. Le Scienze 1998; 355: 68-73.

[101] Sørensen SJ, Bailey M, Hansen LH, Kroer N, Wuertz S. Studying plasmid horizontal transfer in situ: a critical review. Nat Rev Microbiol 2005; 3: 700-10.

[102] Thomas CM, Nielsen KM. Mechanisms of, and barriers to, horizontal gene transfer between bacteria. Nat Rev Microbiol 2005; 3: 711-21.

[103] Paget E, Simonet P. On the track of natural transformation in soil. FEMS Microbiol Ecol 1994; 15: 109-18.

[104] Blum SAE, Lorenz MG, Wackernagel W. Mechanism of retarded DNA degradation and prokaryotic origin of DNases in nonsterile soils. Syst Appl Microbiol 1997; 20: 513-21.

[105] Greaves MP, Wilson MJ. The degradation of nucleic acids and montmorillonite-nucleic-acid complexes by soil microorganisms. Soil Biol Biochem 1970; 2: 257-68.

[106] Crecchio C, Ruggiero P, Curci M, Colombo C, Palumbo G, Stotzky G. Binding of DNA from Bacillus subtilis on montmorillonitehumic acids-aluminum or iron hydroxypolymers: effects on transformation and protection against DNase. Soil Sci Soc Am J Emerg Med 2005; 69: 834-41.

[107] Romanowski G, Lorenz MG, Sayler G, Wackernagel W. Persistence of free plasmid DNA in soil monitored by various methods, including a transformation assay. Appl Environ Microbiol 1992; 5: 3012-9.

[108] Romanowski G, Lorenz MG, Wackernagel W. Use of polymerase chain reaction and electroporation of Escherichia coli to monitor the persistence of extracellular plasmid DNA introduced into natural soils. Appl Environ Microbiol 1993; 59: 3438-46.

[109] Vettori C, Stotzky G, Yoder M, Gallori E. Interaction between bacteriophage PBS1 and clay minerals and transduction of Bacillus subtilis by clay-phage complexes. Environ Microbiol 1999; 1: 34755.

[110] Vettori C, Gallori E, Stotzky G. Clay minerals protect bacteriophage PBS1 of Bacillus subtilis against inactivation and loss of transducing ability by UV radiation. Can J Microbiol 2000; 46: 770-3.

[111] De Vries J, Heine M, Harms K, Wackernagel W. Spread of recombinant DNA by roots and pollen of transgenic potato plants, identified by highly specific biomonitoring using natural transformation of an Acinetobacter sp. Appl Environ Microbiol 2003; 69: 4455-62.

[112] Nielsen KM, Van Elsas JD, Smalla K. Transformation of Acinetobacter sp. strain BD413 ( $p F G 4 D n p t I I)$ with transgenic plant DNA in soil microcosms and effects of kanamycin on selection of transformants. Appl Environ Microbiol 2000; 66: 1237-42.

[113] Douville M, Gagne F, McKay J, Masson L, Blaise C. Tracking the source of Bacillus thuringiensis Cry $1 \mathrm{Ab}$ toxin in the environment. Biochem Syst Ecol 2005; 33: 219-22.

[114] Douville M, Gagne F, Blaise C, Andre C. Occurrence and persistence of Bacillus thuringiensis (Bt) and transgenic Bt corn $c r y l A b$ gene from an aquatic environment. Ecotoxicol Environ Saf 2007; 66: 195-203.

[115] Icoz I, Stotzky G. Fate and effects of insect-resistant $B t$ crops in soil ecosystems. Soil Biol Biochem 2008b; 40: 559-86.

[116] EcoStrat. Critique of Monsanto's environmental safety assessment for Cry3Bb1 Bt corn. In Appendix A, Zurich, April 25 [online], 2002. Available from http://www.ucsusa.org/assets/documents/food_and_environment/appendixa.pdf

[117] Icoz I, Stotzky G. Cry3Bb1 protein from Bacillus thuringiensis in root exudates and biomass of transgenic corn does not persist in soil. Transgen Res 2008a; 17: 609-20.

[118] Vettori C, Calamai L, Yoder M, Stotzky G, Gallori E. Adsorption and binding of AmpliTaq DNA polymerase on the clay minerals, 
montmorillonite and kaolinite. Soil Biol Biochem 1999; 31: 58793.

[119] Wang H, Ye Q, Wang W, Wu L, Wu W. Cry1Ab protein from Bt transgenic rice does not residue in rhizosphere soil. Environ Pollut 2006; 143: 449-55.

[120] Ahmad A, Wilde GE, Zhu KY. Detectability of Coleopteranspecific Cry3Bb1 protein in soil and its effect on nontarget surface and below-ground Arthropods. Environ Entomol 2005; 34: 385-94.

[121] Vaughn T, Cavato T, Brar G, et al. A method of controlling corn rootworm feeding using a Bacillus thuringiensis protein expressed in transgenic maize. Crop Sci 2005; 45: 931-8.

[122] U.S. EPA. Preliminary Risk and Benefit Assessments for Bt PlantPesticide, US EPA, Washington, DC. SAP Report No. 2000-07, Sets of Scientific Issues being considered by the Environmental Protection Agency 2001.

[123] Kuiper HA, Kleter GA, Noteborn HP, Kok EJ. Assessment of the food safety issues related to genetically modified foods. Plant $\mathrm{J}$ 2001; 27: 503-28.

[124] Van Gundy SD. In: Page AL, Miller RH, Keeney DR, Eds. Nematodes. Methods of Soil Analysis, Part 2. American Society of Agronomy: Madison, WI 1982; pp. 1124-8.

[125] Stotzky G, Broder MW, Doyle JD, Jones RA. Selected methods for the detection and assessment of ecological effects resulting from the release of genetically engineered microorganisms to the terrestrial environment. Adv Appl Microbiol 1993; 38: 1-98.

[126] Koskella J, Stotzky G. Larvicidal toxins from Bacillus thuringiensis subspp. kurstaki, morrisoni (strain tenebrionis), and israelensis have no microbicidal or microbiostatic activity against selected bacteria, fungi, and algae in vitro. Can J Microbiol 2002; 48: 262-7.

[127] Egorov NS, Yudina, TC, Baranov AY. Correlation between the insecticidal and antibiotic activities of the parasporal crystals of Bacillus thuringiensis. Mikrobiologiya 1990; 59: 448-52.

[128] Yudina TG, Mil'ko ES, Egorov NS. Sensitivity of Micrococcus luteus dissociation variants to $\delta$-endotoxins of Bacillus thuringiensis. Mikrobiologiya 1996; 63: 365-9.

[129] Yudina TG. Comparison of antibacterial activity of the parasporal bodies from various bacilli. Izvestiya Akademii Nauk 1996; Series Biology 5: 451-2.

[130] Yudina TG, Burtseva LI. Activity of $\delta$-endotoxins of four Bacillus thuringiensis subspecies against prokaryotes. Mikrobiologiya 1997; 66: 25-31.

[131] Abbott A. Transgenic trials under pressure in Germany. Nature 1996; 380: 94.

[132] Kowalchuk GA, Bruinsma M, Van Veen JA. Assessing responses of soil microorganisms to GM plants. Trends Ecol Evol 2003; 18: 403-10.

[133] Lilley AK, Bailey MJ, Cartwright C, Turner SL, Hirsch PR. Life in earth: the impact of GM plants on soil ecology? Trends Biotechnol 2006; 24: 9-14.

[134] Stoger E, Sack M, Fischer R, Christou P. Plantibodies: applications, advantages and bottlenecks. Curr Opin Biotechnol 2002; 13: 161-6.

[135] Sabharwal N, Icoz I, Saxena D, Stotzky G. Release of the recombinant proteins, human serum albumin, $\beta$-glucuronidase, glycoprotein B from human cytomegalovirus, and green fluorescent protein, in root exudates from transgenic tobacco and their effects on microbes and enzymatic activities in soil. Plant Physiol Biochem 2007; 45: 464-9.

[136] Goodey AR. The production of heterologous plasma proteins. Trends Biotechnol 1993, 11: 430-3.

[137] Daniell H. Production of human serum albumin in transgenic crops without interfering with food and feed production. ISB News Report 2003.

[138] Ma JK. Genes, greens, and vaccines. Nat Biotechnol 2000; 18: 1141-2.

[139] Farran I, Sanchez-Serrano JJ, Medina JF, Prieto J, Mingo-Castel AM. Targeted expression of human serum albumin to potato tubers. Transgen Res 2002; 11: 337-46.

[140] Sijmons PC, Dekker BM, Schrammeijer B, Verwoerd TC, Van den Elzen PJ, Hoekema A. Production of correctly processed human serum albumin in transgenic plants. BioTechnology 1990; 8: 21721.

[141] Horn ME, Woodard SL, Howard JA. Plant molecular farming: systems and products. Plant Cell Rep 2004; 22: 711-20.
[142] Kyle JW, Galvin N, Vogler C, Grubb JH, Eds. GUS ( $\beta$ glucuronidase) assay in animal tissue. Academic Press: San Diego, 1992.

[143] Kusnadi AR, Hood EE, Witcher DR, Howard JA, Nikolov ZL. Production and purification of two recombinant proteins from transgenic corn. Biotechnol Prog 1998; 14: 149-55.

[144] Witcher DR, Hood EE, Peterson D, et al. Commercial production of $\beta$-glucuronidase (GUS): a model system for the production of proteins in plants. Mol Breed 1998; 4: 301-12.

[145] Sudan C, Prakash S, Bhomkar P, Jain S, Bhalla-Sarin N. Ubiquitous presence of $\beta$-glucuronidase (GUS) in plants and its regulation in some model plants. Planta 2006; 224: 853-64.

[146] Ogras TT, Gozukirmizi N. Expression and inheritance of GUS gene in transgenic tobacco plants. Tr J Bot 1999; 23: 297-302.

[147] Hood EE. From green plants to industrial enzymes Enzyme Microbial Technol 2002; 30: 279-83.

[148] Murdter TE, Sperker B, Kivisto KT, et al. Enhanced uptake of doxorubicin into bronchial carcinoma: $\beta$-glucuronidase mediates release of doxorubicin from a glucuronide prodrug (HMR 1826) at the tumor site. Cancer Res 1997; 57: 2440-5.

[149] Bosslet KRS, Blumrich M, Czech J, et al. Elucidation of the mechanism enabling tumor selective prodrug monotherapy. Cancer Res 1998; 58: 1195-201.

[150] Chourasia MK, Jain SK. Pharmaceutical approach to colontargeted drug delivery systems. J Pharm Sci 2003; 6: 33-6.

[151] Gonczol E, deTaisne C, Hirka G, et al. High expression of human cytomegalovirus (HCMV)-gB protein in cells infected with a vaccinia-gB recombinant: the importance of the $\mathrm{gB}$ protein in HCMV immunity. Vaccine 1991; 9: 631-7.

[152] Marshall GS, Rabalais GP, Stout GG, Waldeyer SL. Antibodies to recombinant derived glycoprotein B after natural human cytomegalovirus infection correlate with neutralizing activity. J Infect Dis 1992; 165: 381-4.

[153] Lopper M, Compton T. Disulfide bond configuration of human cytomegalovirus glycoprotein B. J Virol 2002; 76: 6073-82.

[154] Tackaberry ES, Dudani AK, Prior F, et al. Development of biopharmaceuticals in plant expression systems: cloning, expression and immunological reactivity of human cytomegalovirus glycoprotein B (UL55) in seeds of transgenic tobacco. Vaccine 1999; 17: 3020-9.

[155] Ward W. In: Smith KC, Ed. Energy transfer processes in bioluminescence. Photochemical and Photobiological Reviews. Plenum, New York 1979; pp. 1-57

[156] Harper BK, Mabon SA, Leffel SM, et al. Green fluorescent protein as a marker for expression of a second gene in transgenic plants. Nat Biotechnol 1999; 17: 1125-9.

[157] Leffel SM, Mabon SA, Stewart CN Jr. Applications of green fluorescent protein in plants. Biotechniques 1997; 23: 912-8.

[158] Dick RP. In: Doran, et al. Eds. Defining soil quality for a sustainable environment. Soil enzyme activities as indicators of soil quality. SSSA Special Publ., SSSA, Madison, WI 1994; pp. 10724.

[159] Blackwood CB, Buyer JS. Soil microbial communities associated with $B t$ and non-Bt corn in three soils. J Environ Qual 2004; 33: 832-6.

[160] Brusetti L, Francia P, Bertolini C, et al. Bacterial communities associated with the rhizosphere of transgenic $\mathrm{Bt} 176$ maize (Zea mays) and its non-transgenic counterpart. Plant Soil Biol Biochem 2004; 266: 11-21.

[161] Donegan KK, Palm CJ, Fieland VJ, et al. Changes in levels, species and DNA fingerprints of soil microorganisms associated with cotton expressing the Bacillus thuringiensis var. kurstaki endotoxin. Appl Soil Ecol 1995; 2: 111-24.

[162] Donegan KK, Shaller DL, Stone JK, et al. Microbial populations, fungal species diversity, and plant pathogen levels in field plots of potato plants expressing the Bacillus thuringiensis var. tenebrionis endotoxin. Transgen Res 1996; 5: 25-35.

[163] Griffiths BS, Caul S, Thompson J, et al. Soil microbial and faunal community responses to $B t$ maize and insecticide in two soils. J Environ Qual 2006; 35: 734-41.

[164] Devare MH, Jones CM, Thies JE. Effect of Cry3Bb transgenic corn and tefluthrin on the soil microbial community: biomass, activity, and diversity. J Environ Qual 2004; 33: 837-43.

[165] Naef A, Zesiger T, Defago G. Impact of transgenic Bt maize residues on the mycotoxigenic plant pathogen Fusarium 
graminearum and the biocontrol agent Trichoderma atroviride. $\mathrm{J}$ Environ Qual 2006; 35: 1001-9.

[166] Shen RF, Cai H, Gong WH. Transgenic Bt cotton has no apparent effect on enzymatic activities or functional diversity of microbial communities in rhizosphere soil. Plant Soil 2006; 285: 149-59.

[167] Wu WX, Ye QF, Min, H. Effects of straws from $B t$ transgenic rice on selected biological activities in water-flooded soil. Eur J Soil Biol 2004a; 40: 15-22.

[168] Wu WX, Ye QF, Min H, Duan XJ, Jin WM. Bt transgenic rice straw affects the culturable microbiota and dehydrogenase and phosphatase activities in a flooded paddy soil. Soil Biol Biochem 2004b; 36: 289-95.

[169] Flores S, Saxena D, Stotzky G. Transgenic Bt plants decompose less in soil than non-Bt plants. Soil Biol Biochem 2005; 37: 107382.

[170] Baumgarte S, Tebbe CC. Field studies on the environmental fate of the Cry1 Ab Bt-toxin produced by transgenic maize (MON810) and its effect on bacterial communities in the maize rhizosphere. Mol Ecol 2005; 14: 2539-51.

[171] Fang M, Kremer RJ, Motavalli PP, Davis G. Bacterial diversity in rhizospheres of nontransgenic and transgenic corn. Appl Environ Microbiol 2005; 71: 4132-6.

[172] Griffiths BS, Caul S, Thompson J, et al. A comparison of soil microbial community structure, protozoa, and nematodes in field plots of conventional and genetically modified maize expressing the Bacillus thuringiensis Cry1 Ab toxin. Plant Soil 2005; 275: 13546.

[173] Clark BW, Coats JR. Subacute effects of Cry1 Ab Bt corn litter on the earthworm Eisenia fetida and the springtail Folsomia candida. Environ Entomol Exp Appl 2006; 35: 1121-9.

[174] Al-Deeb MA, Wilde GE, Blair JM, Todd TC. Effect of $B t$ corn for corn rootworm control on nontarget soil microarthropods and nematodes. Environ Entomol 2003; 32: 859-65.

[175] Cowgill SE, Bardgett RD, Kiezebrink DT, Atkinson HJ. The effect of transgenic nematode resistance on non-target organisms in the potato rhizosphere. J Appl Ecol 2002; 39: 915-23.

[176] Sims SR, Martin JW. Effect of Bacillus thuringiensis insecticidal proteins Cry1A(b), Cry1A(c), CryIIA, and CryIIIA on Folsomia candida and Xenylla grisea (Insecta: Collembola). Pedobiologia 1997; 41: 412-6.

[177] Yu L, Berry RE, Croft BA. Effects of Bacillus thuringiensis toxins in transgenic cotton and potato on Folsomia candida (Collembola: Isotomidae) and Oppia nitens (Acari: Orbatidae). J Econ Entomol 1997; 90: 113-8.

[178] Escher N, Kach B, Nentwig W. Decomposition of transgenic Bacillus thuringiensis maize by microorganisms and woodlice Porcello scaber (Crustacea: Isopoda). Basic Appl Entomol 2000; 1: 161-9.

[179] Pont B, Nentwig W. Quantification of Bt-protein digestion and excretion by the primary decomposer Porcellio scaber, fed with two Bt-corn varieties. Biocontrol Sci Technol 2005; 15: 341-52.

[180] Wandeler H, Bahylova J, Nentwig W. Consumption of two Bt and six non-Bt corn varieties by the woodlouse Porcellio scaber. Basic Appl Ecol 2002; 3: 357-65.

[181] Cowgill SE, Atkinson HJ. A sequential approach to risk assessment of transgenic plants expressing protease inhibitors: effects on nontarget herbivorous insects. Transgenic Res 2003; 12: 439-49.

[182] Manachini B, Lozzia GC. First investigations into the effects of $B t$ corn crop on Nematofauna. Boll Zool Agric Bachic Ser II 2002; 34: 85-96.

[183] De Vaufleury A, Kramarz PE, Binet P, et al. Exposure and effects assessments of Bt-maize on non-target organisms (gastropods, microarthropods, mycorrhizal fungi) in microcosms. Pedobiologia 2007; 51: 185-94.

[184] Kramarz PE, De Vaufleury A, Zygmunt PM, Verdun C. Increased response to cadmium and Bacillus thuringiensis maize toxicity in the snail Helix aspersa infected by the nematode Phasmarhabditis hermaphrodita. Environ Toxicol Chem 2007; 26: 73-9.

[185] Castaldini M, Turrini A, Sbrana C, et al. Impact of Bt corn on rhizospheric and soil eubacterial communities and on beneficial mycorrhizal symbiosis in experimental microcosms. Appl Environ Microbiol 2005; 71: 6719-29.

[186] Rui YK, Yi GX, Zhao J, et al. Changes of $B t$ toxin in the rhizosphere of transgenic Bt cotton and its influence on soil functional bacteria. World J Microbiol Biotechnol 2005; 21: 127984.

[187] Turrini A, Sbrana C, Nuti MP, Pietrangeli B, Giovannetti M. Development of a model system to assess the impact of genetically modified corn and aubergine plants on arbuscular mycorrhizal fungi. Plant Soil 2004; 266: 69-75.

[188] Sun CX, Chen LJ, Wu ZJ, Zhou LK, Shimizu H. Soil persistence of Bacillus thuringiensis (Bt) toxin from transgenic Bt cotton tissues and its effect on soil enzyme activities. Biol Fertil Soil 2007; 43: 617-20.

[189] Dinel H, Schnitzer M, Saharinen M, et al. Extractable soil lipids and microbial activity as affected by $B t$ and non $B t$ maize grown on a silty clay loam soil. J Environ Sci Health B 2003; 38: 211-9.

[190] Zeilinger AR, Andow DA, Zwahlen C, Stotzky G. Earthworm populations in a northern U.S. Cornbelt soil are not affected by long-term cultivation of $B t$ maize expressing Cry $1 \mathrm{Ab}$ and Cry3Bb proteins. Soil Biol Biochem 2010, doi:10.1016/j.soilbio.2010.04.004 .

[191] Devare M, Londoňo-R LM, Thies JE. Neither transgenic Bt maize (MON863) nor tefluthrin insecticide adversely affect soil microbial activity or biomass: A 3-year field analysis. Soil Biol Biochem 2007; 39: 2038-47.

[192] Donegan KK, Seidler RJ, Fieland VJ, et al. Decomposition of genetically engineered tobacco under field conditions: persistence of the proteinase inhibitor I product and effects on soil microbial respiration and protozoa, nematode, and microarthropod populations. J Appl Ecol 1997; 34: 767-77.

[193] Donegan KK, Seidler RJ, Doyle JD, et al. A field study with genetically engineered alfalfa inoculated with recombinant Sinorhizobium meliloti: Effects on the soil ecosystem. J Appl Ecol 1999; 36: 920-36.

[194] Icoz I, Andow D, Zwahlen C, Stotzky G. Is the Cry1Ab protein from Bacillus thuringiensis (Bt) taken up by plants from soils previously planted with $B t$ corn and by carrot from hydroponic culture? Bull Environ Contam Toxicol 2009; 83: 48-58.

[195] Saxena D, Stotzky G. Bt toxin uptake from soil by plants. Nat Biotechnol 2001c; 19: 199.

[196] Brinkmann N, Tebbe CC. Leaf-feeding larvae of Manduca sexta (Insecta, Lepidoptera) drastically reduce copy numbers of aadA antibiotic resistance genes from transplastomic but maintain intact aadA genes in their feces. Environ Biosaf Res 2007; 6: 121-33.

[197] Gallori E, Franchi M, Rinaldi L, Vettori C. Interspecific transformation of Bacillus subtilis by clay-bound DNA in nonsterile soil. Symbiosis 1998; 25: 311-22.

[198] Marsh P, Wellington EMH. Phase-host interactions in soil. FEMS Microbiol Ecol 1994; 15: 99-108.

[199] Nielsen KM, Van Weerelt MDM, Berg TN, Bones AM, Hagler AN, Van Elsas JD. Natural transformation and availability of transforming DNA to Acinetobacter calcoaceticus in soil microcosms. Appl Environ Microbiol 1997; 63: 1945-52.

[200] Pietramellara G, Dal Canto L, Vettori C, Gallori E, Nannipieri P. Effects of air-drying and wetting cycles on the transforming ability of DNA bound on clay minerals. Soil Biol Biochem 1997; 29: 5561.

[201] Richter B, Smalla K. Screening of rhizosphere and soil bacteria for transformability. Environ Biosaf Res 2007; 6: 91-9.

[202] Donnarumma F, Paffetti D, Stotzky G, Giannini R, Vettori C. Potential gene exchange between Bacillus thuringiensis subsp. kurstaki and Bacillus spp. in soil in situ. Soil Biol Biochem 2010; doi:10.1016/j.soilbio.2010.03.014.

[203] Arakawa T, Chong DKX, Langridge WHR. Efficacy of a food plant-based oral cholera toxin B subunit vaccine. Nature Biotechnol 1998; 16: 292-7.

[204] Arntzen CJ. High-tech herbal medicine. Plant-based Vaccines 1997; 15: 221-2.

[205] Fischer R, Drossard J, Commandeur U, Schillberg S, Emans N. Towards molecular farming in the future: moving from diagnostic protein and antibody production in microbes to plants. Biotechnol Appl Biochem 1999a; 30: 101-8.

[206] Fischer R, Drossard J, Emans N, Commandeur U, Hellwig S. Towards molecular farming in the future: Pichia pastoris-based production of single-chain antibody fragments. Biotechnol Appl Biochem 1999b; 30: 117-20.

[207] Fischer R, Emans N, Schuster F, Hellwig S, Drossard J. Towards molecular farming in the future: using plant-cell-suspension 
cultures as bioreactors. Biotechnol Appl Biochem 1999c; 30: 10912.

[208] Giddings G, Allison G, Brooks D, Carter A. Transgenic plants as factories for biopharmaceuticals. Nat Biotechnol 2000; 18: 1151-5.

[209] Giddings G. Transgenic plants as protein factories Curr Opin Biotechnol 2001; 12: 450-4.

[210] Goldstein DA, Thomas JA. Biopharmaceuticals derived from genetically modified plants. QJM. Int J Med 2004; 97: 705-16.

[211] Hood EE, Jilka JM. Plant-based production of xenogenic proteins. Curr Opin Biotechnol 1999; 10: 382-6.

[212] Leite A, Kemper EL, Da Silva MJ, et al. Expression of correctly processed human growth hormone in seeds of transgenic tobacco plants. Mol Breed 2000; 6: 47-53.

[213] Marvier M. Pharmaceutical crops have a mixed outlook in California. California Agric 2007; 61: 59-66.

[214] Spok A. Molecular farming on the rise-GMO regulators still walking a tightrope. Trends Biotechnol 2007; 25: 74-82.

[215] Steinberg J. Edible-Vaccine Trial: No Small Potatoes. J NIH Res 1996; 8: 26-8.

[216] Caplan R. Raising risk: field testing of genetically engineered crops in the United States field testing of genetically engineered crops in the United States. In Report: Environment California Research and Policy Center. Environ California Res 2003: pp. 1-101.

[217] Fischer R, Liao YC, Hoffmann K, Schillberg S, Emans N. Molecular farming of recombinant antibodies in plants. Biol Chem 1999d; 380: 825-39.
[218] Kapusta J, Modelska A, Figlerowicz M, et al. A plant-derived edible vaccine against hepatitis B virus. FASEB J 1999; 13: 17969.

[219] Larrick JW, Yu L, Chen J, Jaiswal S, Wycoff K. Production of antibodies in transgenic plants. Res Immunol 1998; 149: 603-8.

[220] Ma JK, Hiatt A, Hein M, et al. Generation and assembly of secretory antibodies in plants. Science 1995; 268: 716-9.

[221] Russell DA, Ed. Feasibility of Antibody Production in Plants for Human Therapeutic Use. Springer-Verlag: New York , NY, 1999.

[222] Staub JM, Garcia B, Graves J, et al. High-yield production of a human therapeutic protein in tobacco chloroplasts. Nat Biotechnol 2000; 18: 333-8.

[223] Thanavala Y, Mahoney M, Pal S, et al. Immunogenicity in humans of an edible vaccine for hepatitis B. Proc Natl Acad Sci USA 2005; 102: $3378-82$.

[224] Walmsley AM, Arntzen CJ. Plants for delivery of edible vaccines. Curr Opin Biotechnol 2000; 11: 126-9.

[225] Watson J, Koya V, Leppla SH, Daniell H. Expression of Bacillus anthracis protective antigen in transgenic chloroplasts of tobacco, a non-food/feed crop. Vaccine 2004; 22: 4374-84.

[226] Stotzky G. In: Elliott LF, Lynch JM, Eds. Physical, chemical, and biological soil characteristics that may affect the establishment of microbial inocula in soil. The International Workshop on Establishment of Microbial Inocula in Soil, 1995. Am J Alt Agric $1995 ; 54-5$.

(c) Saxena et al.; Licensee Bentham Open.

This is an open access article licensed under the terms of the Creative Commons Attribution Non-Commercial License (http: //creativecommons.org/licenses/by$\mathrm{nc} / 3.0 /$ ) which permits unrestricted, non-commercial use, distribution and reproduction in any medium, provided the work is properly cited. 